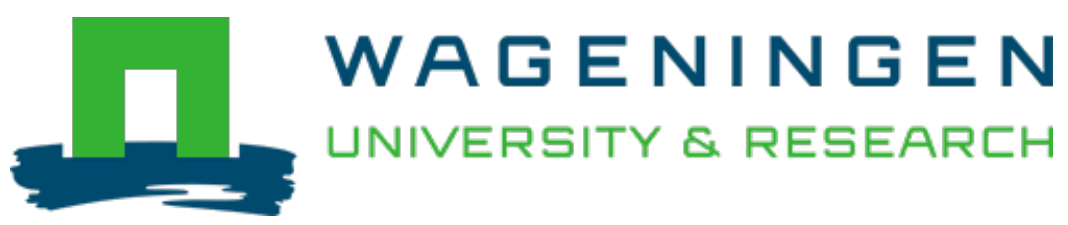

\title{
Price decline, land rental markets and grain production in the North China Plain
}

China Agricultural Economic Review

Wang, Qian; Li, Fan; Yu, Jin; Fleskens, Luuk; Ritsema, Coen J.

https://doi.org/10.1108/CAER-04-2019-0066

This publication is made publicly available in the institutional repository of Wageningen University and Research, under the terms of article $25 \mathrm{fa}$ of the Dutch Copyright Act, also known as the Amendment Taverne. This has been done with explicit consent by the author.

Article $25 \mathrm{fa}$ states that the author of a short scientific work funded either wholly or partially by Dutch public funds is entitled to make that work publicly available for no consideration following a reasonable period of time after the work was first published, provided that clear reference is made to the source of the first publication of the work.

This publication is distributed under The Association of Universities in the Netherlands (VSNU) 'Article $25 \mathrm{fa}$ implementation' project. In this project research outputs of researchers employed by Dutch Universities that comply with the legal requirements of Article $25 \mathrm{fa}$ of the Dutch Copyright Act are distributed online and free of cost or other barriers in institutional repositories. Research outputs are distributed six months after their first online publication in the original published version and with proper attribution to the source of the original publication.

You are permitted to download and use the publication for personal purposes. All rights remain with the author(s) and / or copyright owner(s) of this work. Any use of the publication or parts of it other than authorised under article $25 \mathrm{fa}$ of the Dutch Copyright act is prohibited. Wageningen University \& Research and the author(s) of this publication shall not be held responsible or liable for any damages resulting from your (re)use of this publication.

For questions regarding the public availability of this publication please contact openscience.library@wur.nl 


\section{Price decline, land rental markets and grain production in the North China Plain}

\author{
Qian Wang \\ College of Economics and Management, Northwest A\&F University, \\ Yangling, China and \\ Soil Physics and Land Management Group, Wageningen University and Research, \\ Wageningen, The Netherlands \\ Fan Li \\ Development Economics Group, Wageningen University and Research, \\ Wageningen, The Netherlands \\ Jin $\mathrm{Yu}$ \\ College of Economics and Management, Northwest A\&F University, \\ Yangling, China, and \\ Luuk Fleskens and Coen J. Ritsema \\ Soil Physics and Land Management Group, Wageningen University and Research, \\ Wageningen, The Netherlands
}

\begin{abstract}
Purpose - This study examines the heterogeneous correlations between rural farmers' land renting behavior and their grain production when they experienced a significant price decline.

Design/methodology/approach - We used well-timed panel data obtained from a two-round survey held in 2013 and 2017 among 621 households in the North China Plain. The empirical analyses were conducted by using the pooled ordinary least squares (OLS) and fixed effects models.

Findings - Rural tenants were having heterogeneous responses in land renting behavior and agricultural production when there was a price decline. A group of optimistic tenants (as professional farmers) were more likely to enlarge the farm scale for grain production through land rental markets but decrease variable investment levels (and subsequently decreased productivity) to cope with price decline. In contrast, nonprofessional farmers (the other rural tenants) were rather pessimistic about market performance, and they significantly decreased their grain production area to cope the price decline, but there was no decrease in grain productivity through reducing variable inputs.

Originality/value - This study contributes to the extant literature on the relationship between farmers' land renting-in behavior and agricultural production. By dividing the tenants into professional and nonprofessional farmers, we argue that there is a significant heterogeneous correlation between rural tenants' land renting behavior and grain production when farmers experience a price decline.
\end{abstract}

Keywords Price decline, Land rental market, Grain production, Heterogeneous strategies, North China Plain Paper type Research paper

\section{Introduction}

A crucial challenge to achieve sustainable agricultural growth in many developing countries is the efficient utilization of limited land resources. Developing countries, in general, are

The authors acknowledge the following financial support: the Natural Science Foundation of China (No. 71874139, 71573208), Northwest A\&F University (No. Z109021312), Shaanxi Western Development Institute (No. 2015XBYD001), Ministry of Science and Technology of the People's Republic of China (No. 2017YFE0181100) and China Scholarship Council (No. 201706300088).
Land rental markets in the North China Plain

Received 14 April 2019

Revised 29 July 2019

16 December 2019

28 April 2020

22 August 2020

Accepted 5 October 2020

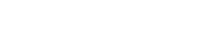


smallholder farming countries with fragmented farmland in each household (Hazell et al., 2010), and the land use efficiency is rather low (Otsuka et al., 2016; Foster and Rosenzweig, 2017). Land consolidation through land rental markets is an important approach to solve land fragmentation (Du et al., 2018). Policymakers in developing countries have been enthusiastic about the development of land rental markets, regardless of whether the land is privately or collectively owned (Holden and Otsuka, 2014).

The land rental market has attracted substantial attention from scholars worldwide since land can be transferred from low-productive to high-productive households and subsequently improve agricultural productivity and land use efficiency (Chamberlin and Ricker-Gilbert, 2016). A large number of early studies focused on the determinants of smallholders' land renting behavior (e.g. off-farm employment, Jin and Deininger, 2009; land tenure security, Holden and Otsuka, 2014), and the effect of land rental markets on smallholder's agricultural production (Gautam and Ahmed, 2019). However, these early studies often treated all tenants as a homogeneous group in agricultural production without considering the potential heterogeneous nature of farmers' land using behavior. Without identifying these heterogeneous natures, findings about land renting behavior and the effect of land rental behavior on agricultural productivity could become rather inconsistent. For instance, when more resources and labors are allocated to cash crops, tenants' renting-in land for cash crop production might decrease grain productivity (Govereh and Jayne, 2003).

Among the heterogeneous natures of the tenants, one particular issue that stands out is how tenants respond to the agricultural commodity price change, particularly when a price decline happens. The agricultural commodity price is an important determinant affecting farmers' comparative advantage in agricultural production (Dawe and Timmer, 2012), so there is no doubt that the price change will affect farmers' agricultural production and land rental behavior. There are two things attracting our attention. First, households' land rental behavior may not change as fast as the agricultural commodity price because it is often acknowledged that the land rental contract has a sticky nature in terms of duration and compensation under the supervision of local governments and village committees (Tang et al., 2019). This sticky nature of the land rental contact indicates that once the land rental contract is signed, changes in agricultural commodity prices could not affect the enforcement of the contract easily without mutual agreements. If the renegotiation cost (or contact cost) is prohibitively high, both the lessor and tenant will have to adjust to the new environment (both market and climate environment) until the rental contract ends. Since lessors and tenants cannot instantly cope with market risks (such as a price decline) efficiently, land rental markets might not always achieve a highest efficiency in agricultural production.

Second, previous studies showed that agricultural commodities price volatility could exert a detrimental effect on households' resource allocation and investment decisions like purchasing a farming machine or hiring labors in agricultural production (Ceballos et al., 2017). This is particularly relevant when farmers experience a significant price decline (Zhou and Koemle, 2015). Under a constrained budget, whether tenants should invest in renting-in land or variable inputs (such as chemical fertilizer) is becoming a crucial decision, which is also closely linked to the heterogeneous natures of the tenants and how they conduct their agricultural production.

Despite the significance of the agricultural commodity price change, almost no studies specifically examined the heterogeneous relationship between tenants' land renting behavior and agricultural productivity considering the dynamic fluctuation in agricultural commodity prices (Jin and Jayne, 2013; Gautam and Ahmed, 2019). Therefore, taking the advantage of a well-balanced panel data collected in 2013 and 2017, and a general grain price decline since 2014 in China, in this paper we examine the potential heterogeneous correlations between rural tenants' land renting behavior and their grain production when farmers experienced a grain price decline. To achieve this goal, we used pooled ordinary least squares (OLS) 
regressions and fixed effects models to conduct the empirical analyses with panel survey data of 621 households from the North China Plain.

The contribution of our study can be summarized as follows. First, regarding the literatures, it is one of few studies that investigate the correlation between smallholders' land renting behavior and grain productivity considering the dynamic commodity price changes. Although previous empirical studies intensively examined the role of land rental markets in agricultural production in developing countries, most of these studies did not consider the dynamic nature (or market risks) of agricultural sector. Second, from the policy perspective, disentangling the relationship between agricultural commodity price, land rental markets and agricultural production could improve our understanding on the heterogeneous natures about domestic land rental markets and its relationship with grain production when price changes. In addition, at the microlevel, it can help policymakers to formulate their agricultural policy under different market price conditions by helping them figure out the potential relationship of agricultural commodity price decline, land rental markets and agricultural production, which would benefit both lessors and tenants.

The rest of the paper is organized as follows. In Section 2, we provide some background about the recent grain price decline in China since 2014 and the rapid promotion of land rental markets in the North China Plain, and then we establish our analytical framework. In Section 3, we present the sampling and data collection process. We present the empirical strategies in Section 4, and the results in Section 5. We conclude in Section 6.

\section{Background and analytical framework}

\subsection{Grain price decline in China}

A significant decline in grain price, particularly in maize, has been observed in China since 2014 (Figure 1, more details of grain price decline can be found in the descriptive results section). The cause of such a price decline could be attributed to two main factors. First, joining the World Trade Organization (WTO) in 2001 greatly improved China's international market accessibility (Arnade et al., 2017; Garred, 2018), which not only enabled China to export more labor-intensive agricultural products, but also exposed its domestic grain market to the international market (Hertel et al., 2007). Since 2012, the international grain price has been dramatically declining (Bellmann and Hepburn, 2017), posing a significant challenge to Chinese domestic grain producers (Zhou and Koemle, 2015).

Second, the recent change in China's national grain supporting policy has further aggravated the downturn in maize price (Huang and Yang, 2017). The grain reserve in China had been growing steadily since 2000 due to the price support program (Liu et al., 2017) [1]. By 2013, the national grain storage reached its peak, and the cost of storing a huge amount of grain became enormously high. In 2014, the Chinese central government drastically lowered its national maize reserve, placing a downward pressure on the maize price (NDRC, 2015). In 2015, the government lowered the temporary storage price of maize, and subsequently in 2016, the national supporting policy for maize was replaced by the new "market purchases" policy (Anderson-Sprecher and Ji, 2016). Although there were more factors affecting China's domestic grain price decline (Tadasse et al., 2016), what we concern about is that a significant price decline has been widely observed among rural smallholders in China.

\subsection{The rapid promotion of land rental markets in China}

The Chinese government has been promoting land rental markets since the early 1990s (Deininger and Jin, 2005). However, only recently have land rental markets started to develop rapidly. Data from the National Bureau of Statistics of China (NBSC, 2002, 2010) showed that 


\section{CAER}

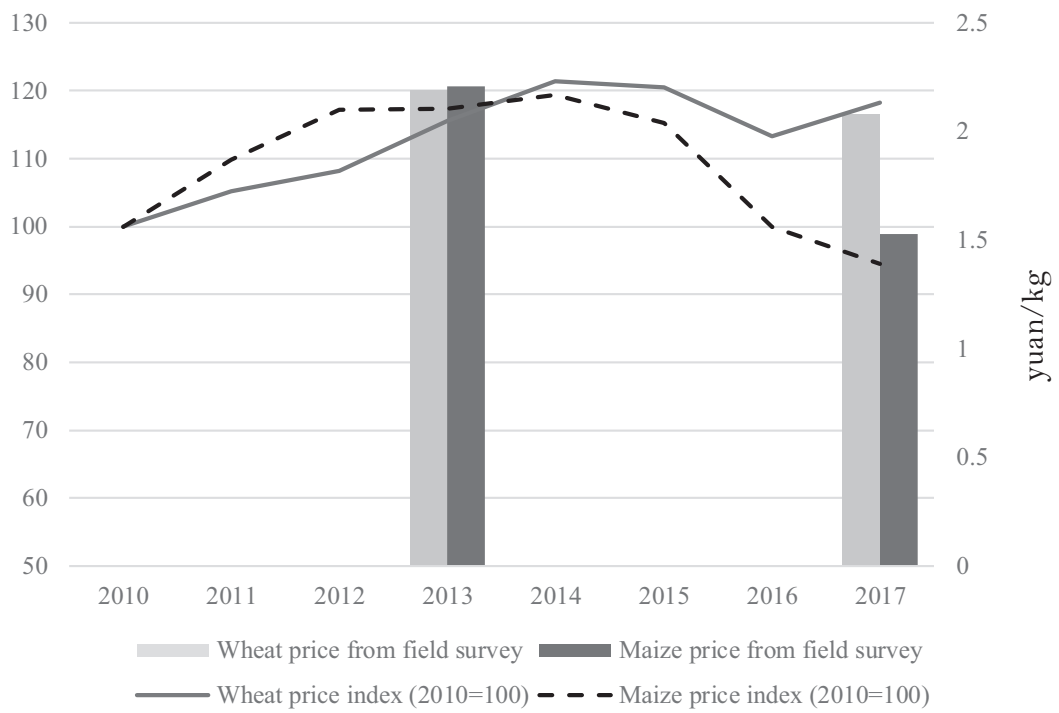

Figure 1.

Changes of grain price from 2010 to 2017

\section{Source(s):}

1) Wheat and maize market price indexes were collected from National Bureau of Statistics of China (NBSC2017) (http://data.stats.gov.cn/easyquery.htm? $\mathrm{cn}=\mathrm{C} 01$ )

2) Market prices of local wheat and maize were obtained from authors' field survey

the percentage of farmland transferred in land rental markets was only $9.5 \%$ in the year 2001 and about $19 \%$ in 2008 . By 2016 , however, about $35 \%$ of farmland was transferred, involving 70m households (Wei and Yan, 2017) [2].

As in many fast growing developing countries, China's land rental markets experience a rapid promotion for two reasons. First, the Chinese central government's continuous progress in securing land tenure rights, such as passing new land tenure security laws, implementing land certification programs, has considerably eased the land contractors' concerns on property rights (Ma et al., 2013; Wang et al., 2015) and greatly increased their willingness to rent-out land. For instance, Cheng et al. (2016) found that China's land certificate program has increased the number of rent-out households by about $4.9 \%$ since 2009 , and the size of rentedout land per transaction has increased by about $0.37 \mathrm{mu}$. Second, uneven regional development accompanied with rising real wages in the manufacturing sector encouraged a significant share of rural labor forces to migrate to urban cities (Wang et al., 2011). This has significantly increased rural households' eagerness to rent-out land (Ji et al., 2018). All these efforts have significantly increased the ready-to-rent-out land in rural areas (Wang et al., 2018).

\subsection{A growing heterogeneity in land rental markets}

From the land demand side, there has been a growing number of entrepreneurial farmers who are motivated to change the traditional agricultural production into a modern agribusiness like family farm (Tan et al., 2013) and professional cooperatives (Deng et al., 2010). These entrepreneurial farmers have been actively involved in land rental markets for agricultural production. In fact, the Chinese central and local governments have been training and educating the so-called "Professional farmers (PFS)" since 2015 to ensure a sustainable and 
modernized agricultural production (State Council, 2018). Various policies and programs, such as farming skill training, machinery services, market accessing and financial supporting programs, have been implemented to aid $P F S$ in agricultural production (Wang, 2013). In 2017, the Chinese central government allocated 1.5bn yuan to subside $1 \mathrm{~m}$ PFs (Li, 2017).

However, in practice, there were no clear definition and criteria in distinguishing $P F$ s from others. In general, $P F$, vaguely defined by the policy, are those who are motivated to become professional in managing agricultural production as an agribusiness, and namely their income are mainly from agricultural production ( $\mathrm{Li}$ and $\mathrm{Li}, 2013)$. Other qualitative studies described PFs as ". . . having capital, mastering technology, and being good at management in farming” (Wang, 2013). Maximizing agricultural profit is $P F s^{\prime}$ primary goal in doing farming work, and a significant part of the profit can be achieved by the economies of scale through renting-in more land. Thus, enlarging farm size through land rental markets is crucial to PFS' agricultural production (Huang and Yang, 2017; Ji et al., 2018).

Counter to the progressive development of PFs, many field studies have observed another group of tenants who also rent-in land but are not motivated (or able) to engage in agricultural production competitively ( $\mathrm{Su}$ et al., 2018). Those farmers are traditional smallholders engaging in agricultural production for self-consumption, and in many cases are left-behinds to take care of the remaining farms (Han and Zhong, 2011). The cause of such phenomenon was partially due to the rapid increase in off-farm employment (Qian et al., 2015; Ye et al., 2017), and personal relationship (Renqing) is a main concern when they rent-in land (Chen et al., 2017). Moreover, under China's current land protection policies, rural smallholders cannot abandon their land for longer than a certain period [3]. Since most migrated rural smallholders still wish to return to their hometowns in the future, it is rational for them to rent-out land to relatives or friends (mostly those left-behinds who are not able to migrate with an off-farm job) for a small or no compensation to secure their claim of the land (Deininger and Jin, 2008; Gao et al., 2012). In this case, we categorized this type of tenants as nonprofessional farmers (non-PFs) since they also rent-in certain land for agricultural production but due to different reasons. In fact, some anecdotal studies (Wu and Ye, 2016; Su et al., 2018) showed that this type of land renting was much more prevalent than PFs in rural China.

\subsection{Analytical framework}

To theoretically analyze how $P F s$ and non-PFs might behave differently when they experienced a significant price decline, we developed a simple analytical framework to capture the essential heterogeneous decision-making process. Assume that farmers are producing in two periods, the present period $(t=1)$ and the future period $(t=2)$, and the objective is to maximize its total revenue in two periods:

$$
\begin{gathered}
\max E\left(\pi_{\text {total }}\right)=E\left(\pi^{1}\right)+E\left(\pi^{2}\right) \\
E\left(\pi^{t}\right)=p^{t} g\left(I_{o}^{t}, I_{\text {land }}^{t} ; H_{i}^{t}\right)-r_{o}^{t} I_{o}^{t}-r_{\text {land }}^{t} I_{\text {land }}^{t} \\
\text { s.t. } r_{o}^{t} I_{o}^{t}+r_{\text {land }}^{t} I_{\text {land }}^{t}=C^{t} \\
p_{E}^{t}=p_{E}^{t-1}+\beta\left(p^{t-1}-p_{E}^{t-1}\right)
\end{gathered}
$$

In the above Eqn (1), $E\left(\pi^{1}\right)$ and $E\left(\pi^{2}\right)$ are the expected profit from the first and the second period [4]. In each period, profit is generated with Eqn (2), in which grain price is determined exogenously, and the profit from grain production is mainly determined by two inputsnamely land $\left(I_{\text {land }}^{t}\right)$ and all other variable inputs $\left(I_{o}^{t}\right) \cdot r_{o}^{t}$ is the price for other inputs at time $t$,
Land rental markets in the North China

Plain

\section{$\longrightarrow$}


and $r_{\text {land }}^{t}$ is the rent of land at time $t$; $C^{t}$ is the budget line for the year $t$ (Eqn (3)). Households decide how to allocate their total budget in land investment and other variable input investments. Following Nerlove's (1958) model, households' expected market price for grain products is derived from Eqn (4), in which $\beta$ captures the effect of the gap between previous actual price and expected grain price. We assume that in period 1 actual grain price $p^{1}$ is lower than farmers previous expectation $p_{E}^{1}\left(p^{1}<p_{E}^{1}\right.$, thus a price decline is defined), and farmers only have their expected future market price $p_{E}^{2}$ in period 2.

Under this general framework, we first examine how non-PFs and autarkic farmers respond to a market price decline, which we assume that both non-PFs and autarkic farmers quickly adjust their price expectation to $p^{1}$ after price decline observed (so that $\beta=1$ and farmer's early expected high price $p_{E}^{1}$ plays no effects on their second period price expectation, and $p_{E}^{2}=p^{1}$ ). Maximizing the two-period profit of the rural farmers is essentially the same as one period model with the same constraint. Taking the standard profit maximization calculus, from the first-order condition (FOC) we can derive the following the result as:

$$
\begin{aligned}
\frac{\partial g}{\partial I_{\text {land }}} & =\frac{(1-\lambda) r_{\text {land }}^{t}}{p^{1}} \\
\frac{\partial g}{\partial I_{o}} & =\frac{(1-\lambda) r_{o}^{1}}{p^{1}}
\end{aligned}
$$

This result indicates that if there is a negative grain price decline $p^{1}<p_{E}^{1}$, non-PFs or autarkic farmers with pessimistic expectation would reduce the land to the level where marginal contribution of the land to total revenue equals to the marginal cost of land (as in Eqn (5)). The same logic also applies to the other inputs $\left(I_{0}\right)$. Thus, an overall decrease of farm size for grain production among non-PFS and autarkic farmers should be observed. Regarding the variable inputs (such as chemical fertilizer), since autarkic farmers did not rent in land and non-PFs only rented-in land to secure land tenure for their relatives or friends, they are more likely operating as subsistence farmers; thus, we might not be able to observe a significant decrease of fertilizer application for grain production.

However, $P F s$ might show a significant different response to the price decline. First, to $P F s$ the previous price decline $\left(p^{t-1}-p_{E}^{t-1}\right)$ might have limited effect over their long-term expectations about the grain market performance (so that $\beta$ is close to zero). This might be because they are not only enjoying benefits from government policies like subsidy program (Yi et al., 2015) and grain supporting price (Anderson-Sprecher and Ji, 2016) but also having access to market-based tools to hedge against price risk such as insurance (Gilbert and Morgan, 2010). Thus, despite the previous price declined, $P F s$ might in fact still expect a high price (as what he has expected earlier) in the second period. In this case, the objective function of rural farmers could be rewritten as follows:

$$
\begin{gathered}
E\left(\pi^{\text {total }}\right)=p^{1} g\left(I_{o}^{1}, I_{\text {land }}^{1} ; H_{i}^{t}\right)+p_{E}^{2} g\left(I_{o}^{2}, I_{\text {land }}^{1} ; H_{i}^{t}\right)-r_{o}^{1}\left(I_{o}^{1}+I_{o}^{2}\right)-2 r_{\text {land land }}^{1} I_{\text {land }}^{1} \\
\text { s.t. } r_{o}^{1} I_{o}^{1}+r_{\text {land }}^{1} I_{\text {land }}^{1}=C^{1} \\
r_{o}^{1} I_{o}^{2}+r_{\text {land }}^{1} I_{\text {land }}^{1}=C^{2} \\
p_{E}^{2}=p_{E}^{1}>p^{1}
\end{gathered}
$$

In Eqn (7), we assume that the price for all variable inputs stay constant over two periods $\left(r_{o}^{1}=r_{o}^{2}\right)$; and land contract is rather sticky (Fabella, 2016), which means that once the land rental contract is signed, both rent and size of the rented land will be fixed for both periods of time, thus, $r_{\text {land }}^{1}=r_{\text {land }}^{2}$ and $I_{\text {land }}^{1}=I_{\text {land }}^{2}$. Rural farmers have to decide whether to rent-in land at period 1 and subject to the budget constraints of both periods. There will be rather 
limited choice space of rural farmers in terms of renting-in land (Liu, 2019). The FOC reveals the following result:

$$
\begin{aligned}
\frac{\partial g}{\partial I_{\text {land }}} & =\frac{\left(1-\lambda^{1}-\lambda^{2}\right) r_{\text {land }}^{1}}{p^{1}+p_{E}^{2}} \\
I_{o}^{1} & =\frac{C^{1}-r_{\text {land }}^{1} I_{\text {land }}^{1}}{r_{o}^{1}}
\end{aligned}
$$

This result (as in Eqn (11)) indicates that if there is a negative grain price decline, PFs will further increase their farm size through land rental markets even when there was a temporary price decline because of high expectation over the long-term grain market price and constraints of the sticky land contract, so that over the two periods the marginal contribution of the land to total revenue would be equal to the marginal cost of renting-in land. However, due to the budget constraints and the increase of rented-in land in period 1, Eqn (12) shows that $P F s$ will have its variable inputs $\left(I_{0}^{1}\right)$ an upper maximum limitation. If the optimal value (as shown in Eqn (6) is higher than the upper limit (Eqn (12)), then we might observe a lower productivity due to under level of variable inputs investment.

Summarizing the above analysis, we could infer that there is an important difference in grain production and market performance between $P F s$ and non-PFs (and/or autarkic farmers). $P F s$ that have a higher expectation toward the future grain market performance are more motivated to benefit from the long-run investments, such as increase area of land rented in and secure long-term land rental contracts. While non-PFs are less optimistic toward future grain market performance and are more responsive to the short-term price decline, simply examining the overall correlations between smallholders' land renting-in behavior and their agricultural production might yield some contradicting results since renting-in land might associate with the increase (Yao and Hamori, 2019) or decrease of agricultural productivity (Liu et al., 2019). In this study, we intend to distinguish rent-in households into PFs and non$P F s$, so that we can better capture the heterogeneities between these two groups of tenants and examine the heterogeneous correlations of farmers' land renting-in behavior and their agricultural productivity when they experience a price decline.

\section{Data}

\subsection{Sampling and data collection}

The data sets we used in this study were collected from two provinces-Henan and Shandong-in the North China Plain (NCP) [5]. We chose these two provinces for two specific reasons. First, the NCP plays a vital role in China's food sufficiency and security. These two provinces together produced about $17 \%$ of the total grain output in 2016 (NBSC, 2017). Second, the farming systems in both provinces are characterized by smallholders with an average farm size of approximately 0.6 ha per household (Zhang et al., 2016). Land transfer has been prevalent after the implementation of a series of policies in the NCP, and lessons drawn from this region could be extended to a much broader scope of China.

We adopted two general principles-the majority principle (major grain producing regions) and the non-neighboring principle (sampled regions should not be adjacent to each other)-to conduct the sampling to ensure a wide representativeness. We first listed all prefectures within each province according to the total grain output (both maize and wheat) in 2012 (NBSC, 2013). We chose two major wheat and maize production prefectures. Following the same protocol, we sampled counties within each prefecture. Eight major grain-producing counties in Henan and Shandong provinces were sampled. Within eight counties, we sampled 21 villages according to the total wheat and maize outputs, and the share of land transferred in 2013. Within each village, we randomly
Land rental markets in the North China Plain

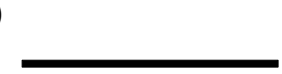


sampled 10-40 households proportional to the village population. In total, 621 households were sampled for the survey. Within these sampled households, there were 499 wheat producers and 445 maize producers in 2013. A detailed sample descriptive analysis is presented in Table 1.

The first-round household survey was carried out in July 2013, immediately after the wheat harvesting period in the NCP [6]. The household questionnaire was administrated with three blocks of information. In the first block, we gathered detailed households' demographic information, including each member' age, education, employment condition, participation in agricultural activities, migrant status, and family size, number of elders, school-aged children, etc. All these variables were used as potential control variables. In the second block, we collected detailed land information, including their contracted land (farm size and number of plots), operational land and renting land (area, rental price, payment forms, and land usage). Specifically, we asked the household head how much land has been contracted since the last village land reallocation. With the detailed land renting information, we could classify if households rented-in land for grain or nongrain production. In the third block, we collected detailed information about the costs of all related farming inputs and final outputs. The inputs include seeds, fertilizers, pesticide and herbicide usage, machinery services and labor costs. With regard to outputs, total outputs and yield of wheat and maize were collected. In addition, we have also collected detailed information related to households' sales price of grain products. We specifically asked how much per kg of wheat (or maize) was sold after their harvest in 2013 [7]. It has to be specifically emphasized that the price we collected in the field survey was farmer's actual sales price, and this sales price might be significantly different from their previous expectations (as we have shown in Section 2.4: Analytical framework).

Moreover, we conducted an interview with a village leader (or accountant) to get basic information about the village general social and geographical characteristics, such as distances from the nearest township and county seat to control for the specific locality effects. The sampling and field survey were administrated with the help of village cadres, with no sensitive topic in the questionnaire to be worried about.

\subsection{Follow-up survey and attrition analysis}

The follow-up survey was conducted in a similar structure in July 2017. We rechecked household demographic characteristics and the land rental behavior. In addition, we collected their inputs and outputs from grain production in 2017. In particular, to measure if a household has experienced price decline, we compared the grain sales price in 2013 and 2017 to see if each household has indeed experienced some price decline. If the sales price of wheat or maize was lower in 2017 than 2013, the surveyed household was categorized as the group that had experienced a price decline. Otherwise, the surveyed household experienced no price decline. Despite the general trend of grain price decline, rural households could still sell their grain products at a better price than others from the same villages. It was concerned that farmer's ability might affect their final observed sales prices; however, we expect farmer's ability would not change so quickly from 2013 to 2017. This variability of price differences in

Table 1.

Sample distribution in NCP in 2013 and 2017

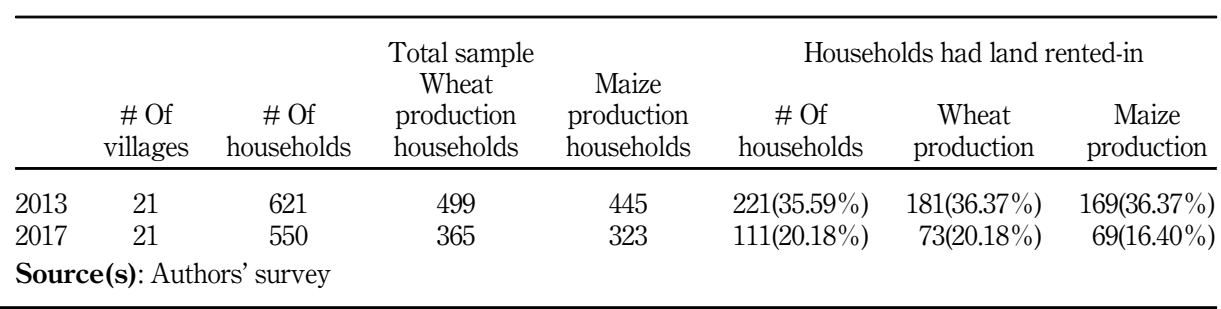


fact enables us to study the heterogeneous correlations between land renting behavior, variable input investments and grain productivities among PFs and non-PFs when they experience a price decline.

To keep the tracking rate, we adopted the following protocol. First, we contacted all sample households by telephone to make appointments. If a household could not be reached, then the village cadres were asked to assist enumerators in reaching them. After this round of follow-up survey, we surveyed 435 households. Second, we visited the remaining households that we could not contact using their registered addresses to continue the follow-up survey. Finally, we tracked 550 households out of 621 households. All these households were surveyed again with the same questionnaire. Detailed sample descriptions are presented in Table A1.

Of the missing 71 households $(11 \%)$ from the baseline survey, many were due to temporary absences. For instance, there were 20 households' members visiting their children or relatives in other places. Other reasons included traveling to nearby cities and working as a temporary employee in the county seat. It is worth noting that, if the missing households were not randomly distributed between rent-in and nonrent households, our estimation might be biased due to attrition. To examine if the missing households were randomly distributed, we conducted the attrition analyses. First, we excluded sampled households if they were not grain producers in both rounds of survey, thus having 546 grain producers in total who were engaged in grain production in 2013. Second, we conducted a group of $t$-tests on all the baseline covariates between the tracked 484 grain producers and the missing 62 grain producers (Appendices, Table A2). Third, we conducted a probit regression, where the lefthand side was a dummy variable indicating whether an individual household was missing in the follow-up survey. On the right-hand side, we controlled all the first-round survey variables. We further controlled for the county- or township-fixed effect. Regression results are presented in the appendices (Table A3). From both attrition analyses ( $t$-test and probit regression), we can see that the missing households in the follow-up survey are rather random; therefore, the subsequent analysis will not be affected by sample attrition [8].

\section{Estimation strategy}

\subsection{Defining professional farmers}

Given the difficulty of identifying $P F s$ and non-PFs in the land rental market directly, we first need to find an appropriate proxy according to certain observed characteristics, which could capture the essential heterogeneous nature of PFs and non-PFs. To simplify our study, we first exclude rural smallholders who rented-in land mainly for nongrain production [9]. This restriction enables us to focus on grain producers' land renting behavior and their productivity changes. With the rest of smallholders who rented-in land for grain production, we defined $P F s$ and non-PFs according to the amount of rent they paid as a core indicator. Specifically, if a household rented-in land for grain production with a rent higher than 3,000 yuan per ha (about USD 462 per ha or 200 yuan per $m u$ ), it was more likely to be a $P F$. Otherwise, if a household rented-in land for grain production with a rent less than 3,000 yuan per ha, it was defined as a $n o n-P F$.

We used the rent of farmland for grain production as the main proxy because it serves the best to capture the essential heterogeneous nature of $P F s$ versus non-PFs. First, the rent that rural tenants have to pay is directly related to their expectations toward the future grain market price. Farmers with a high price expectation are more willing to pay a high rent to secure their rented-in land and might rent-in more land as a long-term investment. While farmers with a low expectation will either be an autarkic farmer who did not transfer land or a tenant that rented in with a minimum rent. Second, from the land supply side, our study was conducted in the NCP, in which both geographical and climatic conditions were much similar. The local cropping structure (winter wheat and summer maize rotation) was rather homogeneous. Thus, we were
Land rental markets in the North China Plain 
less concerned if the rent was determined by those climatic-geographical and/or cropping structure factors. Further, the NCP is a typical smallholder dominant farming area (Zhang et al., 2016), and off-farm employment is rather prevalent for rural farmers (Wang et al., 2019). As long as the rent is higher than the reservation rent, it is rather a reflection of the tenants' willingness in renting-in land. Third, we mainly focused on grain producers instead of cash crop producers. Transportation or other related infrastructures might affect the rent of land for cash crops; however, it plays limited effect on the rent of land for grain production. We used 3,000 yuan per ha as the threshold since many recent studies in the NCP have shown that a rent below was often associated with the kinship-based land rental transaction (He et al., 2016; Shang et al., 2016). From our field interview, $P F s$ were more willing to pay a relatively higher rent to maintain a longer period of rental contract to secure their investments and to reduce the uncertainty about the future. This is particularly the case when there is weak third-party contract enforcement (Ghatak and Pandey, 2000).

Further, to serve as a robustness check, we defined $P F s$ and non-PFs according to the area of rented-in land. As we have mentioned in Section 2, to achieve economies of scale, $P F s$ often rent in more land than non-PFs. In our analysis, if a household rented-in farmland with an area larger than 0.6 ha, we defined it as a $P F$; otherwise, it was defined as a $n o n-P F$. We used the area of 0.6 ha as a threshold for two specific concerns. First, the average area of the contracted land per household in rural NCP is about 0.6 ha (Appendices, Table A1). Renting-in more than 0.6 ha farmland indicates that smallholders had almost doubled their farm size from at least two lessors. This is often difficult to be achieved through the kinship-based land rental transactions. Second, from our field observations, we found a significant discontinuity in rent when the area of rented-in land exceeded 0.6 ha. Such a jump of rent indicates that there might be a transition from the kinship-based land rental contract to a relatively market-based one. In general, the market-based land rental contract between the lessor and tenant is more rigid (Fabella, 2016), which might be in fact preferred by $P F$ s. If both definitions could capture the heterogeneities of $P F s$ versus non-PFs, we expect consistent correlations to be observed from both analyses.

\subsection{Price decline and rural households' land renting strategy}

To investigate the heterogeneous relationship of $P F s$ and non-PFs' land renting-in behavior after the observed price decline in 2017, we first focused on the change in area of the rented-in land, where rented-out land was recorded as negative rented-in. Particularly, we calculated the change in the total area of rented-in land using the following equation:

$$
\Delta I_{i j}=\Delta S_{i j t=2017}-\Delta S_{i j t=2013}
$$

where $\Delta S_{i j t=2017}=S_{i j t=2017}^{\text {in }}-S_{i j t=2017}^{\text {out }}$ and $\Delta S_{i j t=2013}=S_{i j t=2013}^{\text {in }}-S_{i j t=2013}^{\text {out }}$ are the net area of rented-in land in year 2017 and 2013, respectively [10]. Since we also investigated the usage of the rented-in land, we further calculated the change in rented-in land for grain production.

To examine the heterogeneous renting strategies between $P F s$ and non-PFs when there was an observed price decline, we first conducted the following regression:

$$
\Delta I_{i j}=\alpha_{0}+\alpha_{1} R_{i j t=2013}^{P F s}+\alpha_{2} R_{i j t=2013}^{n o n-P F s}+\alpha_{3} S_{i j t=2013}^{P D}+\beta M_{i j t=2013}^{\prime}+\vartheta_{j}+\varepsilon_{i j},
$$

where subscripts $i$ and $j$ represent the $i^{\text {th }}$ household from $j^{\text {th }}$ village, while $R_{i j t=2013}^{P F s}$ and $R_{i j t=2013}^{n o n-P F s}$ are variables that indicate whether household $i$ from village $j$ were $P F s$ or non-PFs in 2013 . We categorized $S_{i j t=2013}^{P D}$ as a dummy variable, it equals to 1 if the sampled farmer's grain sales price in 2017 was lower than 2013; otherwise, it equals to 0 . Although we observe an overall grain price decline in 2014 in the NCP, the sales price of each individual household in 2017 might not always lower than in 2013. $M_{i j t=2013}^{\prime}$ is a vector of household and village characteristics in 2013 that might potentially be correlated with household's renting behavior (a detailed list of control variables is presented in Appendix Table A1). $\vartheta_{j}$ is a vector of 
township dummies to control the locality-specific effects. Since our sampled households are naturally nested (or clustered) within several villages, we cluster the error term $\varepsilon_{i j}$ at the village level in all regressions to control the potential intracluster correlation (Kerry and Bland, 1998; Killip et al., 2004).
Land rental markets in the North China Plain

\subsection{Price decline, land renting-in and grain productivity}

To examine the potential heterogeneous relationship of $P F s$ and non-PFs (versus the autarkic farmers) and their grain productivity with the presence of price decline, we used the following empirical models with grain producers who experienced a price decline and those who did not, respectively. The model is as follows:

$$
Y_{i j t}=\alpha_{0}+\alpha_{1} R_{i j}^{P F s}+\alpha_{2} R_{i j}^{n o n-P F s}+\beta M_{i j}^{\prime}+\delta_{t}+\vartheta_{j}+\varepsilon_{i j t} \mid S_{i j t}^{P D}=1 / 0
$$

where $Y_{i j}$ is the outcome that we are interested in, i.e. grain productivity and fertilizer usage [11], while $M_{i j}^{\prime}$ is the aforementioned vector of household and village characteristics [12]. $\delta_{t}$ is a year dummy variable used to capture all the rest difference due to different years, being equal to 1 in 2017 and 0 in 2013. $S_{i j t}^{P D}=1 / 0$ indicates whether the sampled smallholder has experienced a price decline. $\alpha_{1}$ and $\alpha_{2}$ are the main coefficients that attract our attention. If the coefficients derived from both regression models are significantly different, we would expect that there is a significant heterogeneous correlation between land renting-in behavior and grain productivity among $P F s$ and non-PFs.

To further examine the potential heterogeneous correlations between $P F s^{\prime}$ (and non-PFs') land renting-in behavior and grain productivity when the price decline happens, we make variables $R_{i j t}^{P F s}$ (and $R_{i j t}^{n o n-P F s}$ ) interact with $S_{i j t}^{P D}$ in Eqn (16) to capture the interactive correlation of both factors and tenants' grain productivities. The model specifies as follows:

$$
\begin{aligned}
Y_{i j t}= & \alpha_{0}+\alpha_{1} R_{i j t}^{P F s}+\alpha_{2} R_{i j t}^{n o n-P F s}+\alpha_{3} S_{i j t}^{P D}+\alpha_{4}\left(R_{i j t}^{P F s} \times S_{i j t}^{P D}\right)+\alpha_{5}\left(R_{i j t}^{n o n-P F s} \times S_{i j t}^{P D}\right)+\beta M_{i j}^{\prime} \\
& +\delta_{t}+\vartheta_{j}+\varepsilon_{i j t}
\end{aligned}
$$

where $\left(R_{i j t}^{P F s} \times S_{i j t}^{P D}\right)$ and $\left(R_{i j t}^{n o n-P F s} \times S_{i j t}^{P D}\right)$ capture the interactive correlation of land renting-in and tenants' grain productivity among $P F s$ and non-PFs when experienced a price decline. Empirically, we first ran a pooled OLS regression, assuming that the independent variables in the model correlated with the outcomes in a linear way. Second, to reduce the potential bias due to omitted unobservable households' characteristics, we further ran both regressions using a household level fixed effects (FE) model.

\section{Results}

\subsection{Descriptive results}

In Figure 1, both the national grain price index and our field observations show the consistent trend of grain price decline. This is particular to maize price, which fell by $32 \%$ from 2.2 , yuan per $\mathrm{kg}$ in 2013 to 1.5 yuan per $\mathrm{kg}$ in 2017 (the decline in wheat price was slightly lower). Assuming that maize could yield $7395 \mathrm{~kg}$ per ha on average, with the price decline, rural household were losing about 5176.5 yuan per ha from maize production. Moreover, this loss could be even higher, if we added the loss from wheat production.

In terms of tenants' land renting behavior (including both renting-in and renting-out), the land rental market participation rate was about $46 \%$ in 2013 , which slightly increased to $53 \%$ 
CAER

in 2017 (Figure 2). However, the land rental market experienced a significant structural change, with more households in the NCP motivated to rent out farmland instead of renting-in in 2017.

In Table 2, we compare $P F s$, non-PFs, and autarkic households in terms of land usage, grain productivity and fertilizer cost in 2013 and 2017, respectively. Compared to non-PFs, $P F s$ rented much more land in both 2013 and 2017 (Table 2, rows 2 and 11, columns 3 and 4). In terms of grain productivity, we found that in 2013 both PFs and non-PFs had significantly higher productivity than autarkic smallholders (about 511.897-527.836 kg per ha, Table 2, row 4); while in 2017 non-PFs still had higher productivity than autarkic smallholders, however, $P F s$ showed a lower productivity than autarkic farmers (Table 2, row 13). With regard to farmers' chemical fertilizer input, descriptive results in Table 2 indicate that both $P F s$ and non-PFs had significant higher fertilizer input in maize than autarkic smallholders (Table 2, row 8), while this difference disappeared in 2017 (Table 2, row 17). The reduction was particularly standing out among $P F s$ (from 2801.282 yuan per ha to 2171.049 yuan per ha, Table 2, column 3, row 8 and 17). On the other hand, one interesting point we noted is that the average fertilizer cost in all types of households in fact decreased from 2013 to 2017. This reduction in chemical fertilizer may be partially due to the recent "zero-growth (in chemical fertilizer and pesticide)" policy for green agricultural development (MoA, 2015). This descriptive analysis intuitively indicates that there might be a heterogeneous correlation between tenants' renting-in land and their grain productivity among PFs and non-PFs.

As for the changing status of $P F s$ between 2013 and 2017, we noticed that there were 85 $P F s$ and 50 non-PFs in 2013 (as shown in Table 2). In 2017, 49 tracked PFs changed their status to non-PFs or autarkic smallholders, while another 22 new $P F s$ appeared among the tracked households. Meanwhile, 41 tracked non-PFs changed their status to PFs or autarkic smallholders, and 15 tracked autarkic smallholders became non-PFs in 2017. In sum, among the tracked households 71 households changed their $P F$ status, and 56 households changed

Figure 2.

Percentage of household had rentedin (and -out) land in 2013 and 2017

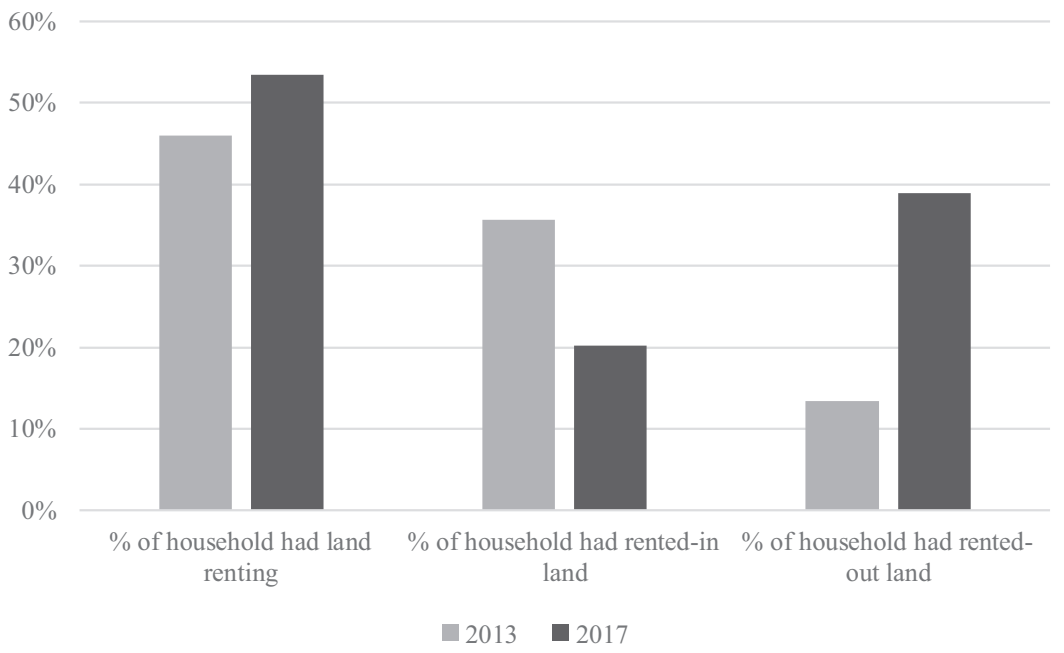

Note(s): There was one type of household that had land both rented-in and rented-out. Therefore, the percentage of households who had land renting behaviors does not equal the sum of percentage of households had land rented-in and rented-out

Source(s): Author's survey 


\begin{tabular}{|c|c|c|c|c|c|c|c|}
\hline & $\begin{array}{c}\text { Total } \\
(1)\end{array}$ & $\begin{array}{c}\text { Autarkic } \\
(2)\end{array}$ & $\begin{array}{l}\mathrm{PFs} \\
(3)\end{array}$ & $\begin{array}{c}\text { Non-PFs } \\
(4)\end{array}$ & $\begin{array}{l}\text { Households with } \\
\text { rented-in land for } \\
\text { nongrain production } \\
\text { (5) } \\
\end{array}$ & $\begin{array}{c}\text { Rent-out } \\
\text { households with } \\
\text { grain production } \\
\text { (6) } \\
\end{array}$ & $\begin{array}{l}\text { Land rental } \\
\text { markets in the } \\
\text { North China } \\
\text { Plain }\end{array}$ \\
\hline \multicolumn{8}{|l|}{ Year of 2013} \\
\hline $\begin{array}{l}\text { 1. Area of } \\
\text { contracted land } \\
\text { (ha) }\end{array}$ & 0.454 & 0.469 & $0.324^{* * * *}$ & 0.415 & $0.617^{* *}$ & 0.471 & \\
\hline $\begin{array}{l}\text { 2. Area of rented-in } \\
\text { land (ha) }\end{array}$ & 0.299 & 0.000 & $2.220 * * *$ & $0.377 * * *$ & $3.427 * * * *$ & 0.000 & \\
\hline $\begin{array}{l}\text { 3. Cultivated area of } \\
\text { wheat (ha) }\end{array}$ & 0.663 & 0.428 & $1.560^{* * * *}$ & $0.664^{* * * *}$ & $0.737^{* * * *}$ & $0.290^{* * *}$ & \\
\hline $\begin{array}{l}\text { 4. Productivity of } \\
\text { wheat (kg per ha) }\end{array}$ & 6699.592 & 6550.103 & $7077.939 * * *$ & $7062.000 * * *$ & 6475.000 & 6755.208 & \\
\hline $\begin{array}{l}\text { 5. Fertilizer use of } \\
\text { wheat (yuan per } \\
\text { ha) }\end{array}$ & 2737.189 & 2673.522 & 2784.848 & 2855.762 & 2917.065* & 2727.364 & \\
\hline $\begin{array}{l}\text { 6. Cultivated area of } \\
\text { maize (ha) }\end{array}$ & 0.657 & 0.315 & $1.393^{* * * *}$ & $0.643 * * *$ & $1.648^{* * * *}$ & 0.271 & \\
\hline $\begin{array}{l}\text { 7. Productivity of } \\
\text { maize (kg per ha) }\end{array}$ & 7395.456 & 7319.787 & $7695.524 * * * *$ & 7288.517 & 7606.338 & 7144.42 & \\
\hline $\begin{array}{l}\text { 8. Fertilizer use of } \\
\text { maize (yuan per } \\
\text { ha) }\end{array}$ & 2601.887 & 2481.875 & $2801.282^{* * *}$ & $2784.832^{* *}$ & 2671.705 & 2643.99 & \\
\hline $\begin{array}{l}\text { 9. Number of } \\
\text { observations }\end{array}$ & 503 & 282 & 85 & 50 & 49 & 37 & \\
\hline \multicolumn{8}{|l|}{ Year of 2017} \\
\hline $\begin{array}{l}\text { 10. Area of } \\
\text { contracted land } \\
\text { (ha) }\end{array}$ & 0.610 & 0.601 & 0.5222 & 0.576 & $0.887^{* * * *}$ & 0.521 & \\
\hline $\begin{array}{l}\text { 11. Area of rented-in } \\
\text { land (ha) }\end{array}$ & 0.329 & 0.000 & $5.351^{* * * *}$ & $0.692 * * *$ & $2.603^{* * * *}$ & 0.000 & \\
\hline $\begin{array}{l}\text { 12. Cultivated area } \\
\text { of wheat (ha) }\end{array}$ & 1.002 & 0.532 & $4.401^{* * * *}$ & $0.778 * *$ & $1.944^{* * * *}$ & $0.238 * * *$ & \\
\hline $\begin{array}{l}\text { 13. Productivity of } \\
\text { wheat (kg per } \\
\text { ha) }\end{array}$ & 7065.453 & 7092.459 & 6968.951 & 7432.229 & 6750.000 & 6957.404 & \\
\hline $\begin{array}{l}\text { 14. Fertilizer use of } \\
\text { wheat (yuan per } \\
\text { ha) }\end{array}$ & 2301.174 & 2314.664 & 2221.866 & 2418.574 & 2053.377 & 2310.624 & \\
\hline $\begin{array}{l}\text { 15. Cultivated area } \\
\text { of maize (in ha) }\end{array}$ & 0.921 & 0.444 & $4.218^{* * * *}$ & $0.792 * * *$ & $1.950^{* * * *}$ & $0.203^{* * *}$ & \\
\hline $\begin{array}{l}\text { 16. Productivity of } \\
\text { maize (kg per } \\
\text { ha) }\end{array}$ & 7291.449 & 7219.55 & 7422.970 & $7775.535^{* *}$ & 7125.000 & 7314.818 & \\
\hline $\begin{array}{l}\text { 17. Fertilizer use of } \\
\text { maize (yuan per } \\
\text { ha) }\end{array}$ & 2210.267 & 2194.821 & 2171.049 & 2249.375 & 1978.71 & 2332.981 & \\
\hline $\begin{array}{l}\text { 18. Number of } \\
\text { observations }\end{array}$ & 367 & 235 & 42 & 21 & 12 & 57 & \\
\hline \multicolumn{8}{|c|}{ 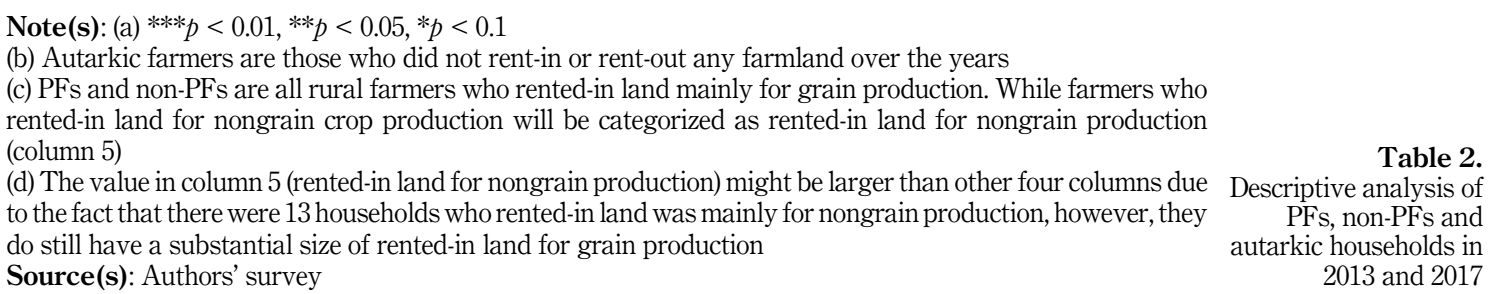 } \\
\hline
\end{tabular}


their non- $P F$ status from 2013 to 2017. These changes provide us with sufficient variation to examine the relationship of tenants' being a $P F$ (or $n o n-P F$ ) and their grain production.

\subsection{Multivariate results}

5.2.1 Heterogeneous land renting strategies. The results of Table 3 were obtained by running Eqn (14). We found that $P F s$ significantly increased the area of rented-in land in year 2017 as a strategic investment to consolidate farmland (about 0.424 ha, Table 3 , row 1 , column 2 ). On the contrary, no significant increase in the rented-in land among non-PFs could be detected (Table 3, row 2, columns 1 and 2). However, by examining the area of rented-in land for grain production, we found no significant change among PFs (no significant increase, Table 3, row 1 ,

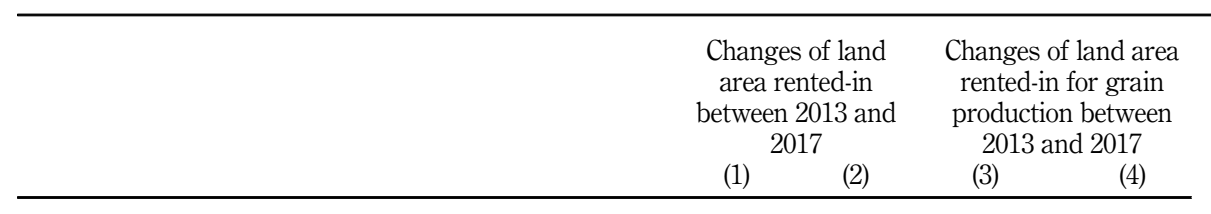

Panel 1: Defined by the rent of land rented-in for grain production

Treatment variables

$\begin{array}{lcccc}\text { Treatment variables } & 0.434^{* *} & 0.424^{* *} & -0.004 & -0.075 \\ \text { 1. Whether a PF in } 2013\left(R^{\mathrm{PFs}}\right), 1=\text { yes } & (0.176) & (0.184) & (0.161) & (0.183) \\ & 0.022 & 0.038 & -0.181^{*} & -0.191^{*} \\ \text { 2. Whether a non-PF in } 2013\left(R^{\mathrm{non}-\mathrm{PFs}}\right), 1=\text { yes } & (0.090) & (0.077) & (0.097) & (0.112) \\ & 0.328^{*} & 0.430^{*} & 0.526^{* *} & 0.565^{* *} \\ \text { 3. Whether rented-in land for nongrain production, } 1 \text { = yes } & (0.194) & (0.228) & (0.241) & (0.274) \\ & 0.106 & 0.022 & 0.189 & 0.122 \\ \text { 4. Experienced a price decline }\left(S^{P D}\right), 1=\text { yes } & (0.117) & (0.183) & (0.165) & (0.155) \\ & \text { Yes } & \text { Yes } & \text { Yes } & \text { Yes } \\ \text { 5. Household grain productivity in 2013 } & \text { Yes } & \text { Yes } & \text { Yes } & \text { Yes } \\ \text { 6. Household characteristics } & - & \text { Yes } & - & \text { Yes } \\ \text { 7. Township dummies } & -0.153 & 0.425 & -0.578^{* *} & 0.121 \\ \text { Constant } & (0.294) & (0.466) & (0.293) & (0.455) \\ & 388 & 388 & 388 & 388 \\ \text { Observations } & 0.578 & 0.585 & 0.239 & 0.259 \\ R \text {-squared } & & & & \end{array}$

Panel 2: Defined by the area of land rented-in for grain production

Treatment variables

8. Whether a PF in $2013\left(R^{\mathrm{PFs}}\right), 1=$ yes

9. Whether a non-PF in 2013 ( $\left.R^{\text {non-PFs }}\right), 1=$ yes

10. Whether rented-in land for nongrain production, $1=$ yes

11. Experienced a price decline $\left(S^{\mathrm{PD}}\right), 1=$ yes

12. Household grain productivity in 2013

13. Household characteristics

14. Township dummies

Constant

Table 3.

Price decline and changes of land area rented-in in the NCP

Observations

$R$-squared

Source(s): Authors' survey

$\begin{array}{cccc}0.799^{* *} & 0.706^{* *} & -0.207 & -0.347 \\ (0.344) & (0.329) & (0.339) & (0.349) \\ 0.026 & 0.010 & -0.132^{* *} & -0.207^{* * *} \\ (0.077) & (0.071) & (0.062) & (0.069) \\ 1.075^{* *} & 1.223^{* *} & -0.228 & -0.267 \\ (0.464) & (0.541) & (0.224) & (0.262) \\ 0.090 & -0.008 & 0.204 & 0.113 \\ (0.101) & (0.147) & (0.164) & (0.158) \\ \text { Yes } & \text { Yes } & \text { Yes } & \text { Yes } \\ \text { Yes } & \text { Yes } & \text { Yes } & \text { Yes } \\ - & \text { Yes } & - & \text { Yes } \\ -0.277 & 0.394 & -0.564 & 0.032 \\ (0.272) & (0.461) & (0.293)^{*} & (0.505) \\ 388 & 388 & 388 & 388 \\ 0.607 & 0.615 & 0.224 & 0.247\end{array}$

Note(s): Robust-clustered standard errors in parentheses, ${ }^{* * *} p<0.01, * * p<0.05,{ }^{*} p<0.1$ 
columns 3 and 4), whereas non-PFs show a slight decrease in grain production areas (Table 3 , row 2 , columns 3 and 4 ).

As a robustness check, in panel 2 when defining $P F s$ and non-PFs according to the area of rented-in land for grain production, we found consistent results (as shown in Table 3, panel 2). We found an increase of about 0.706 ha in the rented-in land among PFs (Table 3, row 8 , column 2), and a significant decrease in the rented-in land area used for grain production (Table 3 , row 8 , columns 3 and 4). Both results clearly indicate that PFs increased the area of land through rental markets in 2017; however, the increased land was not used for grain production; whereas non-PFs had no significant change of rentedin land area during this period. Further, from both models, we noticed that $S^{P D}$ (dummy variable, if the sampled household has experienced a price decline) had no significant correlations with area of rented-in land (Table 3, rows 4 and 11). This result indicates that after considering the potential heterogeneous responses of $P F s$ and non-PFs in land rental behavior, the land rental contract was rather stable despite that farmers experienced a grain price decline.

5.2.2 Price decline, renting-in land and grain productivity. Table 4 shows a significant heterogeneity in $P F s^{\prime}$ and non-PFs' grain productivity. We found that among farmers who experienced no price decline, $P F s$ are associated with a significantly higher grain productivity compared to the autarkic smallholders; while non-PFs did not show any differences in grain productivity (Table 4, rows 1 and 2, column 1). Examining this correlation among farmers who experienced a price decline, we found that, interestingly, $P F S$ did not show any significant positive correlation with grain productivity, whereas non-PFs were performing much better compared to the autarkic smallholders (Table 4, rows 1 and 2, column 2). This result indicates that when tenants experience no price decline $P F S$ might have a significant higher productivity than non-PFs and the autarkic smallholders. However, when there is a price decline, this correlation does not persist.

We further ran Eqn (16) with pooled OLS and household level FE models and with $P F s$ and non-PFs interactions with price decline, respectively. The results showed a significant negative correlation between PFs and their grain productivity (about 0.318-0.339 standard deviations, Table 4, row 3, columns 3 and 4) when they experienced a price decline. Both pooled OLS and FE models showed consistent results (the coefficient $\alpha_{4}=-0.339$ from the FE model was relatively larger and significant at the $10 \%$ level (Table 4, row 3, column 4). For non-PFs, we did not find such a significant correlation with grain productivity (Table 4, row 4, columns 3 and 4) [13].

Results from our robustness analysis (defined according to the area of rented-in land) were all consistent. Using both pooled OLS and FE models, the interaction terms of $R_{i j t}^{P F s} \times S_{i j t}^{P D}$ in Eqn (16) were all negative (Table 4, row 13, columns 3 and 4) [14], suggesting that PFs show a lower productivity when experienced a price decline. Consistent results were also observed for non-PFs.

5.2.3 Price decline, renting-in land and the fertilizer input. Following our analytical framework, to examine whether such a negative correlation between $P F s$ and their grain productivity was due to the reduction of variable inputs, we further examined the correlations between tenants ( $P F s$ and $n o n-P F s$ ) and their chemical fertilizer inputs when experienced a price decline (Table 5). The pooled OLS regression results showed that fertilizer input per ha among $P F s$ was about 0.370 standard deviations lower when they experienced a price decline (Table 5 , row 3, column 3), whereas non-PFs showed no significant negative correlation in the fertilizer input (Table 5, row 4, column 3). Results from the FE models further showed a clear and significant negative correlation in fertilizer input among $P F s$ when experienced a price decline $(-0.429$ standard deviations, Table 5 , row 3 , column 4$)$. In the robustness analysis (Table 5 , panel 2), we found a significant negative correlation in chemical fertilizer input among PFs when experienced the price decline (Table 5, row 13, columns 3 and 4). However, no significant negative correlation was observed among non-PFs (Table 5, row 14, columns 3 and 4). 
CAER

\begin{tabular}{cccc}
\hline Experienced no price & Experienced a price & Pooled & Pooled FE \\
model \\
decline, $S^{\mathrm{PD}}=0$ & decline, $S^{\mathrm{PD}}=1$ & OLS & mol \\
$(1)$ & $(2)$ & $(3)$ & $(4)$ \\
\hline
\end{tabular}

Panel 1: Defined by the rent of land rented-in for grain production

Treatment variables

1. Whether a $\mathrm{PF}\left(R^{\mathrm{PFs}}\right), 1=$ yes

$\begin{array}{cc}0.283^{* * * *} & 0.189 \\ (0.083) & (0.143) \\ 0.081 & 0.342^{* *} \\ (0.100) & (0.133)\end{array}$

2. Whether a non-PF $\left(R^{\text {non-PFs }}\right)$,

$(0.100)$

3. $R^{\mathrm{PFs}} \times S^{\mathrm{PD}}$

$(0.133)$

4. $R^{\mathrm{non} \cdot \mathrm{PFs}} \times S^{\mathrm{PD}}$

5. Experienced a price decline $\left(S^{\mathrm{PD}}\right), 1=$ yes

6. Rented-in for nongrain production, 1 = yes

7. Year dummy, $1=2017$

8. Crop type, $1=$ wheat

9. Household characteristics

10. Township dummies

Constant

0.148

$(0.172)$

$-0.035$

$(0.189)$

Yes

Yes
Yes

Yes
$-0.820 *$

$(0.429)$

1,041

Observations

0.195

Panel 2: Defined by the area of land rented-in for grain production

Treatment variables

11. Whether a $\mathrm{PF}\left(R^{\mathrm{PFs}}\right), 1=$ yes

12. Whether a non-PF ( $\left.R^{\text {non-PFs }}\right)$,

0.116

$1=$ yes
13. $R^{\mathrm{PFs}} \times S^{\mathrm{PD}}$

$0.214 * *$

$(0.085)$

14. $R^{\text {non-PFs }} \times S^{\mathrm{PD}}$

15. Experienced a price decline $\left(S^{\mathrm{PD}}\right), 1=$ yes

16. Rented-in land for nongrain production, 1 = yes

17. Year dummy

$$
0.127
$$

(0.174)

$-0.033$

18. Crop type, 1 = wheat

19. Household characteristics

20. Township dummies

Constant

(0.187)

Yes

Yes

Yes

$-0.809 *$

(0.423)

Observations

$R$-squared

0.193

$0.538^{* * *}$
$(0.152)$


Yes
Yes
Yes
0.074
$(0.483)$
589
0.349

0.192

$(0.154)$

$0.311 * *$

$(0.112)$

$0.531^{* * *}$
$(0.155)$


Yes
Yes
Yes
0.090
$(0.479)$
589
0.349

Table 4.

Land renting-in and grain productivity in the NCP

Note(s): Robust-clustered standard errors in parentheses, $* * * p<0.01, * * p<0.05, * p<0.1$; the $R$-square reported in fixed effect model (column 4 ) are within $R$-square, which is different from the pooled OLS model (column 3) within an overall $R$-square

Source(s): Authors' survey

To further investigate whether the negative correlation in grain productivity among $P F s$ was associated with the reduction in variable inputs (particularly, chemical fertilizer), we conducted a serial mediation analysis (Wen et al., 2004). First, we ran a regression of grain productivity using $R^{P F s}$ and $R^{n o n-P F s}$. Afterward, when the coefficient of $R^{P F s}$ was 


\begin{tabular}{cccc}
$\begin{array}{c}\text { Nondrop } \\
(1)\end{array}$ & $\begin{array}{c}\text { Drop } \\
(2)\end{array}$ & $\begin{array}{c}\text { Pooled OLS } \\
(3)\end{array}$ & $\begin{array}{c}\text { Pooled FE model } \\
(4)\end{array}$ \\
\hline
\end{tabular}

Panel 1: Defined by the rent of land rented-in for grain production

Treatment variables
1. Whether a PF $\left(R^{\mathrm{PFs}}\right), 1=$ yes
$0.251^{*}$
$(0.133)$
0.184
0.136
$(0.128)$
2. Whether a non-PF $\left(R^{\text {non-PFs }}\right), 1=$ yes
(0.096)
3. $R^{\mathrm{PFs}} \times S^{\mathrm{PD}}$
(0.347)
4. $R^{\text {non-PFs }} \times S^{\mathrm{PD}}$
5. Experienced a price decline $\left(S^{\mathrm{PD}}\right), 1=$ yes
6. Rented-in for nongrain production, 1 = yes
7. Year dummy
8. Crop type, $1=$ wheat
9. Household characteristics
10. Township dummies
Constant
Observations
R-squared

$0.403^{* * * *}$
$(0.140)$
0.213
(0.130)
$-0.370^{* * *}$
(0.161)
$-0.071$
(0.253)
0.031
(0.118)
$\begin{array}{lc}0.226 & -0.144 \\ (0.202) & (0.127)\end{array}$
-0.536 ***
(0.121)
Yes Yes
Yes Yes
Yes Yes
0.948* $\quad-0.644$
$(0.462)$
1,041
0.107
0.171
(0.191)
$-0.468^{* * * *}$
(0.123)
Yes
Yes
Yes
0.469
$(0.282)$
1,630
0.134
589
0.212
$0.747 * * *$
(0.175)
0.173
$(0.152)$
$-0.429 * *$
(0.201)
0.256
(0.349)
$-0.174$
(0.145)
0.092
$(0.245)$
$-0.358^{* * * *}$
$(0.132)$
Yes
$-0.128$
(0.566)
1,630
0.226

Land rental markets in the North China

Plain

Panel 2: Defined by the area of land rented-in for grain production

Treatment variables
11. Whether a $\mathrm{PF}\left(R^{\mathrm{PFs}}\right), 1=$ yes
12. Whether a non-PF $\left(R^{\text {non-PFs }}\right), 1=$ yes
$0.316^{*} \quad-0.032$
$(0.168) \quad(0.144)$
$0.163^{* *} \quad 0.308$
$(0.075)$
(0.288)
13. $R^{\mathrm{PFs}} \times S^{\mathrm{PD}}$
14. $R^{\text {non-PFs }} \times S^{\mathrm{PD}}$
15. Experienced a price decline $\left(S^{\mathrm{PD}}\right), 1=$ yes
16. Rented-in for non-grain production, 1 = yes
17. Year dummy
18. Crop type, $1=$ wheat
19. Household characteristics
20. Township dummies
Constant
Observations
$R$-squared

$\begin{array}{cc}0.507 * * * & 0.929 * * * \\ (0.159) & (0.184) \\ 0.248^{* *} & 0.283 * * \\ (0.115) & (0.142) \\ -0.619 * * * & -0.773 * * * \\ (0.160) & (0.207) \\ 0.031 & 0.208 \\ (0.212) & (0.290) \\ 0.048 & -0.115 \\ (0.120) & (0.147) \\ 0.154 & 0.086 \\ (0.193) & (0.244) \\ -0.487 * * * & -0.393 * * * \\ (0.122) & (0.135) \\ \text { Yes } & - \\ \text { Yes } & \text { Yes } \\ \text { Yes } & - \\ 0.441 & -0.116 \\ (0.297) & (0.566) \\ 1,630 & 1,630 \\ 0.137 & 0.229\end{array}$
$\begin{array}{cc}0.224 & -0.158 \\ (0.208) & (0.131)\end{array}$
$-0.544 * * *$
(0.122)
Yes Yes
Yes Yes
Yes
$0.922^{*}$
(0.462)
Yes
(0.485)
589
0.217
$0.507^{* * *}$
$(0.159)$
$0.248^{* *}$
$(0.115)$
$-0.619^{* * *}$
$(0.160)$
$0.929 * *$
$0.283^{* *}$
$(0.142)$
$0.207)$
0.208
0.115
(0.147)
(0.244)
$-0.393^{*}$
-
$-0.116$
$(0.566)$
1,041
0.107

Note(s): Robust-clustered standard errors in parentheses, $* * * p<0.01, * * p<0.05, * p<0.1$; the $R$-square reported in fixed effect model (column 4 ) is within $R$-square, which is different from the pooled OLS model (column 3) within an overall $R$-square

Source(s): Authors' survey

Table 5.

Households' land renting-in and fertilizer cost in NCP 
CAER

significant, then we ran a regression of fertilizer input using $R^{P F s}$ and $R^{\text {non-PFs }}$ as explaining variables. Finally, we ran regression of grain productivity using $R^{P F s}$ and $R^{\text {non-PFs }}$, and fertilizer costs as explaining variables. If all coefficients in step 3 were significant, then a mediating effect would be verified, otherwise the Sobel test should be carried out. Table 6 presents the results of the mediation analysis. The Sobel test produced a value of 1.292 , which was significantly higher than the threshold (0.97), with about $11 \%$ of the total effects mediated through the adjustment of fertilizer reduction among $P F s$.

The above results further reinforced our findings that there is a significant heterogeneity among rural tenants. Rural tenants with a higher expectation of the grain market in the long run will strategically increase their land area (as a long-term investment) even to sacrifice their temporary productivity by reducing variable inputs (short-term benefits) when they experienced a price decline. While rural tenants with low expectations of grain market might simply behave same as subsistence farmers. When they experienced a price decline, they might simply reduce the farm size for grain production. These rural tenants are farmers who rent-in land either because of limited ability to work off-farm or rent-in land to help their relatives and friends to keep the land farmed.

\section{Conclusion and discussion}

In this study, we examine the potential heterogeneity in the relationship between rural tenants' land rental behavior and their grain production when they experienced a price decline in the NCP. The current land rental market might present two heterogeneous types of tenants-professional farmers $(P F S)$ and nonprofessional farmers (non-PFs). PFs are the farmers who are fully engaged in grain production and are managing their farm as a kind of small agribusiness. They are motivated to rent-in land to enlarge their agribusiness and have a rather positive expectation about the grain market performance in the long run. While non$P F$, as a type of tenants in land rental markets, are those who rent-in land might be due to their limited ability to work off-farm, and land tenure security concerns among their relatives or friends. They are not motivated to run their farm as an agribusiness and overall have a rather lower expectation about the grain market performance in the long run. These two types of tenants are essentially different in motivations and expectations about the long-run grain market performance, and thus are having heterogeneous responses (or strategies) when they experienced a price decline. PFs continuously increase their farm size through land rental markets to reach its long-term optimal level. Under the budget constraint, increasing rented-in land when they experienced a price decline might lead to a reduction over variable inputs, which subsequently decreased their grain productivity. While non-PFs show no significant change in land renting behavior. This might be partially due to the fact that non$P F s$ are not enthusiastically engaged in agricultural production, and renting-in land was primarily for securing the land tenure rights for land lessors. Moreover, non-PFs do not show a negative correlation with their grain productivity and the variable inputs might be due to the fact that they are more subsistence farmers (Yang et al., 2018).

Table 6.

The mediating effect of PFs' fertilizer input on grain productivity

\begin{tabular}{|c|c|c|c|c|c|c|}
\hline Variable & Step 1 & Step 2 & Step3 & $Z$ value of sobel test & $\begin{array}{l}\text { Mediating } \\
\text { effect }\end{array}$ & $\begin{array}{c}\text { Mediating effect/total } \\
\text { effect }\end{array}$ \\
\hline$R^{\mathrm{PFS}}$ & $\begin{array}{l}0.324^{* * *} \\
(0.128)\end{array}$ & $\begin{array}{l}0.618^{\text {*** }} \\
(0.161)\end{array}$ & $\begin{array}{l}0.288^{* * *} \\
(0.130)\end{array}$ & 1.292 & 0.036 & 0.110 \\
\hline Fertilizer cost & & & $\begin{array}{c}0.058 \\
(0.042)\end{array}$ & & & \\
\hline
\end{tabular}

Note(s): Robust-clustered standard errors in parentheses, ${ }^{* * *} p<0.01,{ }^{*} p<0.05,{ }^{*} p<0.1$ 
Given the importance of land rental markets and the potential detrimental effect of price decline on agricultural production, understanding rural households' heterogeneous expectations and their heterogeneous responses by balancing the short-term and longterm investments are crucial for future policy designers to improve the land use efficiency through land rental markets. To ultimate the performance of land rental markets, a grain price warning system should be built, and price information should be well-communicated within rural grain producers to facilitate their decision-making regarding the participation in land rental markets. Additionally, comprehensive agricultural services should be provided to grain producers (particularly to $P F S$ ) to improve their agricultural profitability without sacrificing productivity when there is a serious grain price decline.

Although our study has been carefully conducted, there are still a number of unsolved issues that deserve a more careful examination. First, it is rather difficult to distinguish between $P F s$ and non-PFs in the field. We used both the rent and the area of rented-in land as proxies, these indicators might not be accurate, which could underestimate (or overestimate) the true relationship between $P F s^{\prime}$ and non-PFs' land rental behavior and their agricultural productivity. A more accurate indicator for $P F s$ and non-PFs should be designed to capture such underlying differences. Second, employing only two-round panel data provides us with a limited opportunity to explore the dynamic correlations between grain price volatility, household land renting behavior and agricultural productivity. In addition, a large survey sample with continuous measurement of price volatility might be better to examine the causal relationship of $P F s^{\prime}$ and non-PFs' land rental behavior and their grain productivity when experienced a price decline. We expect both the magnitude and length of the price decline to have more profound and heterogeneous effects on land rental markets and agricultural productivity.

\section{Notes}

1. China's central government has implemented a grain price support program to protect grain producers' profitability since 2004. However, it has gradually removed this price protection mechanism since 2013 (Cao et al.,2017). For a period of time there was a coexistence of market price and policy price for wheat and maize. In our study, we refer to smallholders' sales market price since by then most farmers could not sell directly at a reserved price, and farmers cannot always enjoy the policy price.

2. It is not allowed in China to trade farmland property rights, since the land property right is owned by the village communities, and no specific individual owns the property right (Du and Sun, 2011). However, rural households can transfer the land-use rights to other rural households and/or organizations, while retaining land contractual rights.

3. According to the recent "The Law of Land Administration of China," rural households who have abandoned their cultivated farmland for more than two years will not be entitled to the corresponding land.

4. To simplify the theoretical analysis, we assume no value discount over time since these factors are essentially same across PFs and non-PFs. Land is categorized as the one of the fix investments, while all other inputs categorized as variable inputs (assume that complete labor, machinery, fertilizer and other variable inputs markets).

5. The NCP is the largest alluvial plain in East Asia, and it is one of the fastest growing urban areas in the world (Bren et al., 2017).

6. In the NCP, the farming structure is characterized by the rotation of winter wheat and summer maize. By the time we conducted the survey, farmers had just finished wheat harvest in June and planted summer maize. We collected information on the previous season of maize, which was from June 2012 to harvest in October 2012. For wheat, it was the crossover year from October 2012 to June 2013.

7. Although there was a policy price (or floor price policies) about wheat and maize (canceled in 2016) set by the National Food and Strategic Reserves Administration, the price we asked in both surveys was farmer's sales price. In our study, we did not specifically focus on the policy prices because
Land rental markets in the North China Plain 
almost no farmers directly sold to the national reserve company (but rather to a middle-agent), and most of the rural farmers did not directly enjoy this policy price.

8. Although from $t$-test we found some slight differences in two baseline variables (e.g. area of the contracted land, distance from the nearest county), in probit regression analysis, none of these variables were statistically significant. We noticed that households who rented-in land with a low price had slightly significant values, and the coefficient was relatively larger than other coefficients; however, after we compare our results with the results obtained with different imputation methods, our results are rather stable.

9. Farmers who rented-in land for cash crop production might show a significant different orientation in land rental market due to their specific demands on certain characteristics of the land and their different land usages. In our study, we focus on grain producers; thus, if a household rented-in land for nongrain production, we recorded it as cash crop farmers. This is different from the national "new professional farmer training" program, in which large scale professional farmers was specially trained to produce high-value crops (Yan et al., 2019).

10. When the area of rented-in land is less than the rented-out land in a single year, the value will be negative. In our data, there are only a limited number of households that have both rented-in and rented-out land simultaneously.

11. To further explain the changes in grain productivity, we also examined the effect of renting-in land on households' fertilizer input. Many studies showed that with the adoption of a more science-based approach in agriculture, inputs such as fertilizer would play a much more significant role in shaping agricultural productivity (Subbarao, 1985).

12. Particularly, we also indicated whether households had parts of their farmland rented-out as a binary variable. Households who had completely rented-out their farmland were not included in our analysis, since they did not participate in any farming activities.

13. In fact, the fixed effects model showed a significant increase in agricultural productivity among non-PFs after the price decline (Table 4, row 4, column 4).

14. The coefficient of the fixed effects model was negative (as shown in Table 4, row 13 , column 4), but it was statistically significant only at the $15 \%$ significance level. It might be the case that the farmers who had rented-in land larger than 0.6 ha were stressed rent-in.

\section{References}

Anderson-Sprecher, A. and Ji, J. (2016), China's Decision to End Corn Floor Price Shakes Grain and Feed Market, US Department of Agriculture, Foreign Agricultural Service, Washington, DC, GAIN Report CH16027, available at: http://gain.fas.usda.gov/Recent GAIN Publications/Grain and Feed Annual_Beijing_China.

Arnade, C., Cooke, B. and Gale, F. (2017), "Agricultural price transmission: China relationships with world commodity markets", Journal of Commodity Markets, Vol. 7, pp. 28-40.

Bellmann, C. and Hepburn, J. (2017), "The decline of commodity prices and global agricultural trade negotiations: a game changer?", International Development Policy, Vol. 8, pp. 1-23.

Bren, D., Amour, C., Reitsma, F., Baiocchi, G., Barthel, S., Güneralp, B., Erb, K. and Seto, K.C. (2017), "Future urban land expansion and implications for global croplands", Proceedings of the National Academy of Sciences, Vol. 114, pp. 8939-8944.

Cao, H., Zhang, Y. and Sun, H. (2017), "The potential impacts of reforming China's floor price policies on grains,", Chinese Rural Economy, Vol. 11, pp. 1-14 in Chinese.

Ceballos, F., Hernandez, M.A., Minot, N. and Robles, M. (2017), "Grain price and volatility transmission from international to domestic markets in developing countries", World Development, Vol. 94, pp. 305-320.

Chamberlin, J. and Ricker-Gilbert, J. (2016), "Participation in rural land rental markets in Sub-Saharan Africa: who benefits and by how much? Evidence from Malawi and Zambia", American Journal of Agricultural Economics, Vol. 98 No. 5, pp. 1507-1528. 
Chen, Y., Zhong, F. and Ji, Y. (2017), "Why does 'zero rent' exist in farmland transfer: an empirical analysis from the perspective of rent type", China Rural Survey, Vol. 4, pp. 1-14 in Chinese.

Cheng, L., Zhang, Y. and Liu, Z. (2016), "Does land titling program improve farmland renting", Management World, Vol. 1, pp. 88-98 in Chinese.

Dawe, D.C. and Timmer, P.C. (2012), "Why stable food prices are a good thing: lessons from stabilizing prices in Asia”, Global Food Security, Vol. 1, pp. 127-133.

Deininger, K. and Jin, S. (2005), "The potential of land rental markets in the process of economic development: evidence from China", Journal of Development Economics, Vol. 78 No. 1, pp. 241-270.

Deininger, K. and Jin, S. (2008), "Land sales and rental markets in transition: evidence from rural Vietnam", Oxford Bulletin of Economics and Statistics, Vol. 70 No. 1, pp. 67-101.

Deng, H., Huang, J., Xu, Z. and Rozelle, S. (2010), "Policy support and emerging farmer professional cooperatives in rural China", China Economic Review, Vol. 21 No. 4, pp. 495-507.

$\mathrm{Du}, \mathrm{Y}$. and Sun, B. (2011), "The development of Chinese agricultural land transfer system: transaction, concentration and commercialization", Journal of Agricultural Science, Vol. 3 No. 3, p. 269.

Du, X., Zhang, X. and Jin, X. (2018), "Assessing the effectiveness of land consolidation for improving agricultural productivity in China”, Land Use Policy, Vol. 70, pp. 360-367.

Fabella, R.V. (2016), Why Fixed Rent Contracts are Less Prevalent: Weak Third Party Enforcement and Endogenous Principal Type, (No. 2016-06), Discussion Paper, School of Economics, University of the Philippines.

Foster, A.D. and Rosenzweig, M.R. (2017), Are There Too Many Farms in the World? Labor-Market Transaction Costs, Machine Capacities and Optimal Farm Size, Yale University Economic Growth Center, New Haven, Discussion Paper No. 1059, available at: https://ssrn.com/abstract=3037569.

Gao, L., Huang, J. and Rozelle, S. (2012), "Rental markets for cultivated land and agricultural investments in China", Agricultural Economics, Vol. 43, pp. 391-403.

Garred, J. (2018), "The persistence of trade policy in China after WTO accession", Journal of International Economics, Vol. 114, pp. 130-142.

Gautam, M. and Ahmed, M. (2019), "Too small to be beautiful? The farm size and productivity relationship in Bangladesh”, Food Policy, Vol. 84, pp. 165-175.

Ghatak, M. and Pandey, P. (2000), "Contract choice in agriculture with joint moral hazard in effort and risk", Journal of Development Economics, Vol. 63 No. 2, pp. 303-326.

Gilbert, C. and Morgan, W. (2010), Has Food Price Volatility Risen? Department of Economics, University of Trento, Italia, Working Papers 1002.

Govereh, J. and Jayne, T.S. (2003), “Cash cropping and food crop productivity: synergies or trade-offs?”, Agricultural Economics, Vol. 28 No. 1, pp. 39-50.

Han, H. and Zhong, F. (2011), "The effect of remaining land's transfer direction on income allocation after labor migration", Chinese Rural Economy, Vol. 4, pp. 18-25 in Chinese.

Hazell, P., Poulton, C., Wiggins, S. and Dorward, A. (2010), "The future of small farms: trajectories and policy priorities", World Development, Vol. 38 No. 10, pp. 1349-1361.

He, C., Zhou, Y. and Huang, Z. (2016), "Fiscal decentralization, political centralization, and land urbanization in China", Urban Geography, Vol. 37 No. 3, pp. 436-457.

Hertel, T.W., Keeney, R., Ivanic, M. and Winters, L.A. (2007), "Distributional effects of WTO agricultural reforms in rich and poor countries", Economic Policy, Vol. 22 No. 50, pp. 290-337.

Holden, S.T. and Otsuka, K. (2014), "The roles of land tenure reforms and land markets in the context of population growth and land use intensification in Africa", Food Policy, Vol. 48, pp. 88-97.

Huang, J. and Yang, G. (2017), "Understanding recent challenges and new food policy in China”, Global Food Security, Vol. 12, pp. 119-126.

Ji, X., Qian, Z., Zhang, L. and Zhang, T. (2018), "Rural labor migration and households' land rental behavior: evidence from China”, China and World Economy, Vol. 26 No. 1, pp. 66-85.
Land rental markets in the North China Plain 
Jin, S. and Deininger, K. (2009), "Land rental markets in the process of rural structural transformation: productivity and equity impacts from China”, Journal of Comparative Economics, Vol. 37 No. 4, pp. 629-646.

Jin, S. and Jayne, T.S. (2013), "Land rental markets in Kenya: implications for efficiency, equity, household income, and poverty", Land Economics, Vol. 89 No. 2, pp. 246-271.

Kerry, S.M. and Bland, J.M. (1998), "The intracluster correlation coefficient in cluster randomisation", BMJ, Vol. 316 No. 7142 , pp. 1455-1460.

Killip, S., Mahfoud, Z. and Pearce, K. (2004), "What is an intracluster correlation coefficient? Crucial concepts for primary care researchers", The Annals of Family Medicine, Vol. 2 No. 3, pp. 204-208.

Li, Y. (2017), “China to cultivate new type of professional farmer: authority”, People's Daily, available at: http://en.people.cn/n3/2017/0608/c90000-9225956.html.

Li, Q. and Li, H. (2013), "The training of new professional farmers: idea, mechanism and path", Journal of Socialist Theory Guide, Vol. 9, pp. 82-84.

Liu, L. (2019), "Research on interest conflict and its countermeasures of family farm exit", China Land Science, Vol. 33 No. 1, pp. 49-55 in Chinese.

Liu, X., Li, B., Shen, D., Cao, J. and Mao, B. (2017), "Analysis of grain storage loss based on decision tree algorithm", Procedia Computer Science, Vol. 122, pp. 130-137.

Liu, Y., Yan, B., Wang, Y. and Zhou, Y. (2019), "Will land transfer always increase technical efficiency in China?-a land cost perspective", Land Use Policy, Vol. 82, pp. 414-421.

Ma, X., Heerink, N., van Ierland, E., van den Berg, M. and Shi, X. (2013), "Land tenure security and land investments in Northwest China”, China Agricultural Economic Review, Vol. 5 No. 2, pp. 281-307.

Ministry of Agricultural [MoA] (2015), "Ministry of Agricultural about strategic plan in reducing use of chemical fertilizer to zero -growth by 2020 ", available at: http://jiuban.moa.gov.cn/zwllm/ tzgg/tz/201503/t20150318_4444765.htm.

National Bureau of Statistics of China [NBSC] (2002, 2010, 2013, 2017), China Statistical Yearbook, China Statistics Press, Beijing in Chinese.

National Development Research Center of the State Council [NDRC] (2015), "China should cope with the change of food demand structure and the coming peak more efficiently", available at: http:// epaper.21jingji.com/html/2016-03/29/content_36166.htm.

Nerlove, M. (1958), "Distributed lags and demand analysis for agricultural and other commodities", Journal of the American Statistical Association, Vol. 54 No. 285, p. 317.

Otsuka, K., Nakano, Y. and Takahashi, K. (2016), "Contract farming in developed and developing countries", Annual Review of Resource Economics, Vol. 8, pp. 353-376.

Qian, W., Li, B. and Zheng, L. (2015), The Impact of Non-agricultural Employment on Farmland Transfer and Investment in Agricultural Assets: Evidence from China. International Conference of Agricultural Economics, Italy, Milan.

Shang, X., Chang, Q. and Wang, S. (2016), "Study on price mechanism and policy effect of government-dominated rural farmland management rights' transfer", China Population, Resource and Environment, Vol. 26 No. 8, pp. 116-124 in Chinese.

State Council (2018), "The number of new professional farmers surpassed 15 million by the end of 2017", QuanGuo XinXing Zhiye Nongmin Tupo Yiqian Wubai Wan Ren, available at: http:// www.gov.cn/guowuyuan/2018-05/20/content_5292167.htm.

Su, B., Li, Y., Li, L. and Wang, Y. (2018), "How does nonfarm employment stability influence farmers' farmland transfer decisions? Implications for China's land use policy”, Land Use Policy, Vol. 74, pp. 66-72.

Subbarao, K. (1985), "State policies and regional disparity in Indian agriculture", Development and Change, Vol. 16 No. 4, pp. 523-546. 
Tadasse, G., Algieri, B., Kalkuhl, M. and Von Braun, J. (2016), "Drivers and triggers of international food price spikes and volatility", Food Price Volatility and its Implications for Food Security and Policy, Springer, Cham, pp. 59-82.

Tan, M., Robinson, G.M., Li, X. and Xin, L. (2013), "Spatial and temporal variability of farm size in China in context of rapid urbanization”, Chinese Geographical Science, Vol. 23 No. 5, pp. 607-619.

Land rental markets in the North China Plain

Tang, L., Ma, X., Zhou, Y., Shi, X. and Ma, J. (2019), "Social relations, public interventions and land rent deviation: evidence from Jiangsu Province in China", Land Use Policy, Vol. 86, pp. 406-420.

Wang, Y. (2013), "Professional farmers needed for the fields", China Daily. available at: http://www. chinadaily.com.cn/opinion/2013-12/27/content_17199737.htm.

Wang, X., Huang, J., Zhang, L. and Rozelle, S. (2011), "The rise of migration and the fall of selfemployment in rural China's labor market”, China Economic Review, Vol. 22 No. 4, pp. 573-584.

Wang, J., Chen, K.Z., Das Gupta, S. and Huang, Z. (2015), "Is small still beautiful? A comparative study of rice farm size and productivity in China and India”, China Agricultural Economic Review, Vol. 7 No. 3, pp. 484-509.

Wang, Q., Ren, Q. and Yu, J. (2018), “The bargaining power of rural households in land rental markets in main grain production areas", China Rural Survey, Vol. 2, pp. 47-59 in Chinese.

Wang, Q., Qiu, J. and Yu, J. (2019), "Impact of farmland characteristics on grain costs and benefits in the North China Plain", Land Use Policy, Vol. 80, pp. 142-149.

Wei, H. and Yan, K. (2017), China's Rural Development Report (2017): Deepening Reform Comprehensively China's New Engine for Rural Development, China Social Sciences Publishing House, Beijing in Chinese.

Wen, Z., Zhang, L., Hou, J. and Liu, H. (2004), “Testing and application of the mediating effects”, Acta Psychologica Sinica, Vol. 36 No. 5, pp. 614-620.

$\mathrm{Wu}, \mathrm{H}$. and Ye, J. (2016), "Hollow lives: women left-behind in rural China", Journal of Agrarian Change, Vol. 16 No. 1, pp. 50-69.

Yan, M., Wang, B., Zhao, X. and Zhong, T. (2019), "Influence of commercialized production-oriented 'new professional farmers' on the plastic tunnels transition: a case study in Nanjing City", Progress in Geography, Vol. 38 No. 9, pp. 1294-1304.

Yang, G., Zhang, C. and Wen, G. (2018), "Impact of cultivated land transfer on rice farmers' technical efficiency", China Population, Resources and Environment, Vol. 28 No. 5, pp. 142-151 in Chinese.

Yao, W. and Hamori, S. (2019), "The long-run relationship between farm size and productivity", China Agricultural Economic Review, Vol. 11 No. 2, pp. 373-386.

Ye, J., He, C., Liu, J., Wang, W. and Chen, S. (2017), "Left-behind elderly: shouldering a disproportionate share of production and reproduction in supporting China's industrial development", The Journal of Peasant Studies, Vol. 44 No. 5, pp. 971-999.

Yi, F., Sun, D. and Zhou, Y. (2015), "Grain subsidy, liquidity constraints and food security—Impact of the grain subsidy program on the grain-sown areas in China", Food Policy, Vol. 50, pp. 114-124.

Zhang, Y., Li, X., Song, W. and Zhai, L. (2016), "Land abandonment under rural restructuring in China explained from a cost-benefit perspective”, Journal of Rural Studies, Vol. 47, pp. 524-532.

Zhou, D. and Koemle, D. (2015), "Price transmission in hog and feed markets of China", Journal of Integrative Agriculture, Vol. 14 No. 6, pp. 1122-1129. 


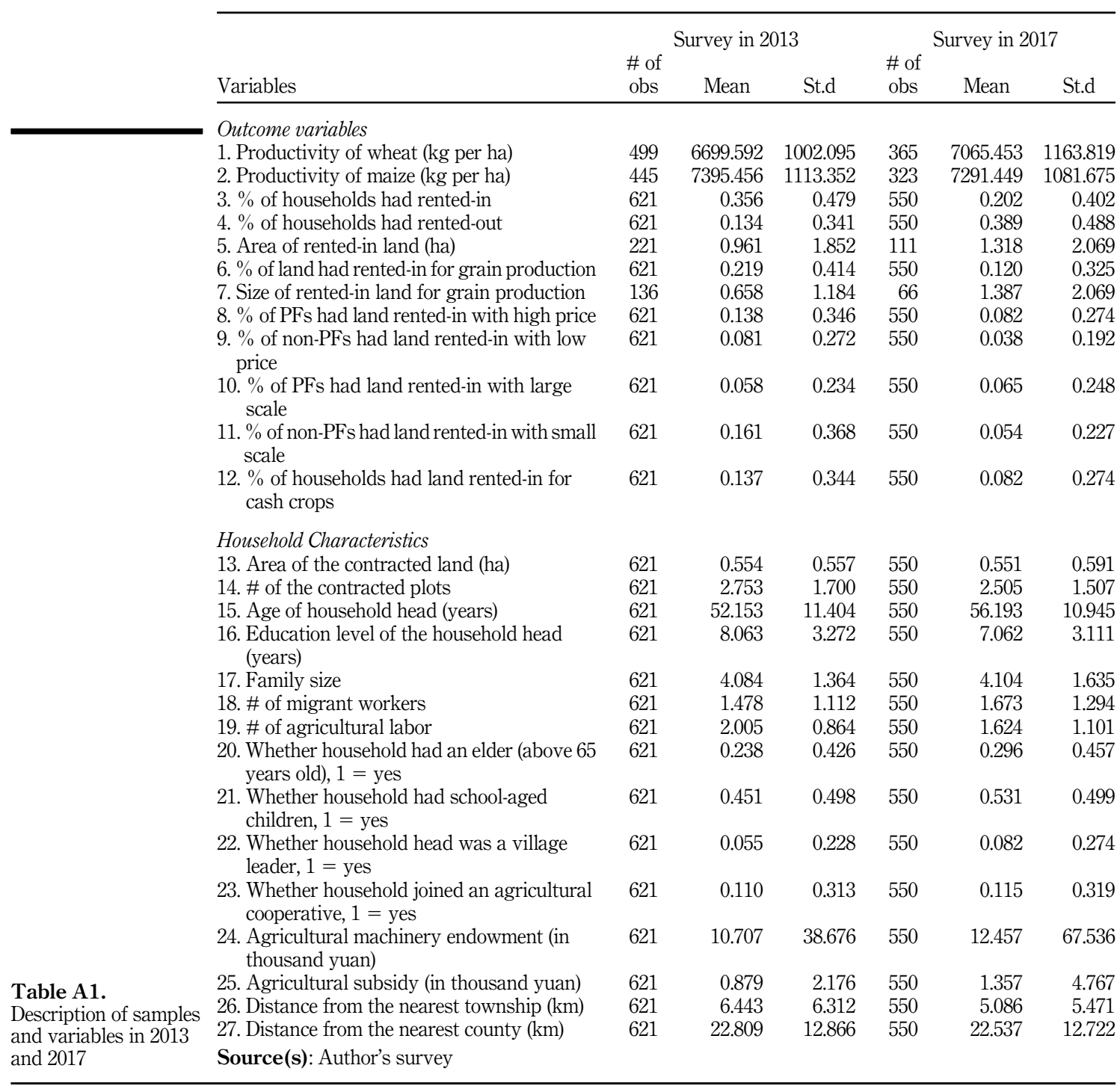




\begin{tabular}{|c|c|c|c|c|c|c|c|}
\hline & \multicolumn{2}{|c|}{ Tracked } & \multicolumn{2}{|c|}{ Non-tracked } & \multirow[b]{2}{*}{ Difference } & \multirow[b]{2}{*}{ S.e } & Land rental \\
\hline & Mean & S.e & Mean & S.e & & & markets in the \\
\hline \multicolumn{7}{|l|}{ Outcome variables } & \\
\hline 1. Productivity of wheat (kg per ha) & 6650.403 & 127.372 & 6706.571 & 47.977 & -56.167 & 136.108 & \\
\hline 2. Fertilizer use per ha of wheat (yuan per ha) & 2686.600 & 95.792 & 2744.366 & 36.081 & -57.767 & 102.362 & \\
\hline 3. Productivity of maize (kg per ha) & 7333.864 & 153.071 & 7403.783 & 56.285 & -69.919 & 163.091 & \\
\hline 4. Fertilizer use per ha of maize (yuan per ha) & 2573.977 & 120.359 & 2605.661 & 44.256 & -31.684 & 128.238 & \\
\hline \multicolumn{8}{|l|}{ Treatment variables } \\
\hline $\begin{array}{l}\text { 5. Rented in land for grain production with } \\
\text { high price, } 1=\text { yes }\end{array}$ & 0.226 & 0.046 & 0.149 & 0.017 & 0.077 & 0.049 & \\
\hline $\begin{array}{l}\text { 6. Rented in land for grain production with } \\
\text { low price, } 1=\text { yes }\end{array}$ & 0.048 & 0.037 & 0.097 & 0.013 & -0.049 & 0.039 & \\
\hline $\begin{array}{l}\text { 7. Rented in land for grain production with } \\
\text { large scale, } 1=\text { yes }\end{array}$ & 0.065 & 0.032 & 0.066 & 0.011 & -0.002 & 0.034 & \\
\hline $\begin{array}{l}\text { 8. Rented in land for grain production with } \\
\text { small scale, } 1=\text { yes }\end{array}$ & 0.210 & 0.049 & 0.180 & 0.018 & 0.030 & 0.052 & \\
\hline $\begin{array}{l}\text { 9. Rented in land for non-grain production in } \\
2013,1=\text { yes }\end{array}$ & 0.065 & 0.040 & 0.120 & 0.014 & -0.055 & 0.043 & \\
\hline 10. Rented-out land in $2013,1=$ yes & 0.097 & 0.037 & 0.093 & 0.013 & 0.004 & 0.039 & \\
\hline 11. Sales price of wheat (yuan per kg) & 2.186 & 0.026 & 2.188 & 0.009 & -0.002 & 0.028 & \\
\hline 12. Sales price of maize (yuan per kg) & 2.066 & 0.013 & 2.074 & 0.005 & -0.008 & 0.014 & \\
\hline \multicolumn{8}{|l|}{ Household characteristics } \\
\hline 13. Area of the contracted land (ha) & 0.405 & 0.066 & 0.554 & 0.024 & $-0.149 * *$ & 0.070 & \\
\hline 14. \# of contracted plots & 2.742 & 0.203 & 2.811 & 0.073 & -0.069 & 0.216 & \\
\hline 15. Age of household head (years) & 51.048 & 1.413 & 52.614 & 0.506 & -1.565 & 1.501 & \\
\hline $\begin{array}{l}\text { 16. Education level of the household head } \\
\text { (years) }\end{array}$ & 8.081 & 0.416 & 7.996 & 0.149 & 0.085 & 0.442 & \\
\hline 17. Family size & 4.065 & 0.170 & 4.169 & 0.061 & -0.105 & 0.181 & \\
\hline 18. \# of migrant work within household & 1.516 & 0.140 & 1.517 & 0.050 & -0.000 & 0.149 & \\
\hline 19. \# of agricultural labor within household & 2.194 & 0.099 & 2.083 & 0.035 & 0.111 & 0.105 & \\
\hline $\begin{array}{l}\text { 20. Whether household had an elder (above } \\
65 \text { years old), } 1=\text { yes }\end{array}$ & 0.210 & 0.054 & 0.236 & 0.019 & -0.026 & 0.057 & \\
\hline $\begin{array}{l}\text { 21. Whether household had school-aged } \\
\text { children, } 1=\text { yes }\end{array}$ & 0.387 & 0.063 & 0.465 & 0.023 & -0.078 & 0.067 & \\
\hline $\begin{array}{l}\text { 22. If the household head was a village leader, } \\
1=\text { yes }\end{array}$ & 0.081 & 0.029 & 0.054 & 0.011 & 0.027 & 0.031 & \\
\hline $\begin{array}{l}\text { 23. If household joins an agricultural } \\
\text { cooperative, } 1=\text { yes }\end{array}$ & 0.081 & 0.037 & 0.093 & 0.013 & -0.012 & 0.039 & \\
\hline $\begin{array}{l}\text { 24. Agricultural machinery endowment (in } \\
\text { thousand yuan) }\end{array}$ & 11.396 & 5.222 & 11.390 & 1.869 & 0.006 & 5.546 & \\
\hline 25. Agricultural subsidy (in thousand yuan) & 0.806 & 0.293 & 0.974 & 0.105 & -0.167 & 0.311 & \\
\hline 26. Distance from the nearest town $(\mathrm{km})$ & 22.173 & 1.653 & 22.560 & 0.592 & -0.388 & 1.756 & \\
\hline 27. Distance from the nearest county $(\mathrm{km})$ & 3.919 & 0.698 & 5.814 & 0.250 & $-1.895 * *$ & 0.741 & \\
\hline Observations & 484 & & & 62 & & & Table A2. \\
\hline \multicolumn{7}{|c|}{$\begin{array}{l}\text { Note(s): Robust clustered-standard error in parentheses, }{ }^{* * *} p<0.01,{ }^{* *} p<0.05,{ }^{*} p<0.1 \\
\text { Source(s): Authors' survey }\end{array}$} & $\begin{array}{l}\text { Results of } t \text {-test for } \\
\text { attrition analysis }\end{array}$ \\
\hline
\end{tabular}


Households missing in 2017 field survey,

(1)

$1=$ yes

(2)

(3)

(4)

\section{Treatment variables}

1. Rented in land for grain production with a high rent, $1=$ yes

$\begin{array}{cc}0.008 & -0.058 \\ (0.188) & (0.190) \\ -0.473^{*} & -0.502^{*} \\ (0.258) & (0.256)\end{array}$

2. Rented in land for grain production with a low price, $1=$ yes

$(0.258)$

3. Rented in land for grain production at a large scale, $1=$ yes

4. Rented in land for grain production at a small scale, $1=$ yes

5. Rented in land for non-grain production, 1 = yes

6. Sales price of wheat in 2013 (yuan per kg)

7. Sales price of maize in 2013 (yuan per kg)

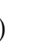

Household characteristics

8. Area of the contracted land in 2013 (ha)

9. \# of contracted plots in 2013

10. Age of household head in 2013 (years)

11. Education level of the household head in 2013 (years)

12. Family size in 2013

13. \# of migrant work within household in 2013

14. \# of agricultural labor within household in 2013

15. Whether household had an elder (above 65 years old) in 2013, $1=$ yes

16. Whether household had school-aged children in $2013,1=$ yes

17. If household head a village leader in $2013,1=$ yes

18. If household joined an agricultural cooperative in $2013,1=$ yes

19. Agricultural machinery endowment in 2013 (in thousand yuan)

20. Agricultural subsidy in 2013 (in thousand yuan)

21. Distance from the nearest town $(\mathrm{km})$

22. Distance from the nearest county $(\mathrm{km})$

23. County dummies

24. Township dummies

Constant

Table A3.

Observations

Note(s): Robust-clustered standard errors in parentheses, ${ }^{* * *} p<0.01,{ }^{* *} p<0.05,{ }^{*} p<0.1$

Source(s): Authors' survey

$\begin{array}{cc}-0.188 & -0.253 \\ (0.323) & (0.340) \\ -0.176 & -0.243 \\ (0.158) & (0.152) \\ -0.018 & -0.056 \\ (0.276) & (0.273) \\ 0.185 & 0.210 \\ (0.383) & (0.397) \\ -0.529 & -0.707 \\ (0.741) & (0.707)\end{array}$

$\begin{array}{llll}-0.348 & 0.002 & -0.390 & -0.011\end{array}$

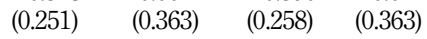

$\begin{array}{llll}0.002 & -0.007 & 0.008 & -0.002\end{array}$

$\begin{array}{llll}(0.060) & (0.076) \quad(0.060) \quad(0.074)\end{array}$

$\begin{array}{llll}-0.012 & -0.012 & -0.013 & -0.013\end{array}$

$\begin{array}{llll}(0.008) & (0.008) & (0.008) & (0.008)\end{array}$

$\begin{array}{llll}0.004 & 0.004 & 0.002 & 0.003\end{array}$

$(0.036) \quad(0.036) \quad(0.036) \quad(0.036)$

$\begin{array}{llll}-0.024 & -0.031 & -0.018 & -0.027\end{array}$

$\begin{array}{llll}(0.087) \quad(0.088) & (0.085) \quad(0.087)\end{array}$

$\begin{array}{llll}-0.036 & -0.039 & -0.033 & -0.037\end{array}$

$\begin{array}{llll}(0.113) & (0.123) \quad(0.112) \quad(0.123)\end{array}$

$\begin{array}{llll}0.136 & 0.116 & 0.133 & 0.111\end{array}$

$\begin{array}{llll}(0.096) & (0.096) & (0.095) & (0.095)\end{array}$

$\begin{array}{llll}0.134 & 0.164 & 0.125 & 0.161\end{array}$

$\begin{array}{llll}(0.269) & (0.277) & (0.270) & (0.277)\end{array}$

$\begin{array}{llll}-0.214 & -0.215 & -0.205 & -0.210\end{array}$

$\begin{array}{llll}(0.190) & (0.197) & (0.192) & (0.199)\end{array}$

$\begin{array}{llll}0.342 & 0.332 & 0.355 & 0.341\end{array}$

$\begin{array}{llll}(0.309) & (0.314) & (0.315) & (0.325)\end{array}$

$\begin{array}{llll}0.090 & -0.003 & 0.136 & 0.035\end{array}$

$\begin{array}{llll}(0.489) \quad(0.527) \quad(0.483) \quad(0.519) & 0.000)\end{array}$

$\begin{array}{llll}0.000 & 0.000 & 0.000 & 0.001\end{array}$

$\begin{array}{llll}(0.001) & (0.001) \quad(0.002) \quad(0.002)\end{array}$

$\begin{array}{llll}-0.022 & -0.026 & -0.021 & -0.026\end{array}$

$\begin{array}{llll}(0.046) & (0.057) \quad(0.046) \quad(0.058)\end{array}$

$\begin{array}{llll}-0.001 & -0.001 & -0.001 & 0.002\end{array}$

$\begin{array}{llll}(0.005) & (0.013) & (0.006) & (0.013)\end{array}$

$\begin{array}{llll}-0.030 & -0.048 & -0.037 & -0.053\end{array}$

$\begin{array}{llll}(0.024) & (0.032) & (0.025) & (0.033)\end{array}$

$\begin{array}{llll}\text { Yes } & - & \text { Yes }\end{array}$

$\begin{array}{llll}- & \text { Yes } & - & \text { Yes }\end{array}$

$\begin{array}{llll}0.358 & 0.680 & 0.359 & 0.745\end{array}$

$\begin{array}{cccc}(1.744) & (1.818) & (1.721) & (1.783) \\ 546 & 502 & 546 & 502\end{array}$ results

Source(s): Authors' survey 
Supplementary material

The supplementary material is available online for this article.

Jin Yu can be contacted at: yujin@nwsuaf.edu.cn

Corresponding author
Land rental markets in the North China

Plain

For instructions on how to order reprints of this article, please visit our website: www.emeraldgrouppublishing.com/licensing/reprints.htm Or contact us for further details: permissions@emeraldinsight.com 